\title{
THE CORE-OBLIQUE DISTINCTION IN SOME AUSTRONESIAN LANGUAGES OF INDONESIA AND BEYOND
}

\author{
I Wayan Arka* \\ The Australian National University \\ wayan.arka@anu.edu.au
}

\begin{abstract}
This paper explores the nature of core-oblique distinctions in some Austronesian languages of Indonesia, focusing on the intermediate status between core and oblique categories. It proposes a core index, a novel method to determine the core status of an argument. Core index evidence shows that there is a cline running from syntactically core to non-core (oblique), and that the degree of coreness in Indonesian and Balinese shows striking parallelism. The proposed core-index-based analysis allows us to claim syntactic transitivity with confidence and to resolve successfully the controversial transitivity problem of the Indonesian bare verb construction. The analysis advances our understanding of the nature of semi-core arguments, syntactic transitivity, symmetricality of voice system, and alternative argument realisations, not only in Indonesian and Balinese, but also in other typologically different Austronesian languages of central and eastern Indonesia and beyond. Importantly, the core-index study also provides a means for cross-linguistic comparative analysis of the unusual alternative pattern of applicativisation whereby no core promotion is involved. The paper also discusses how the gradient nature of the core-oblique distinction, particularly semi-coreness of arguments, poses a challenge for any theory that posits discrete classes of relations.
\end{abstract}

Keywords: core argument, oblique, grammatical relation, Austronesian, symmetricality

\begin{abstract}
Abstrak
Makalah ini membahas pemilahan argumen inti dan oblik dalam beberapa bahasa Austronesia di Indonesia dan sekitarnya, dengan fokus pada kajian atas argument yang yang berstatus antara, ada diantara inti dan oblik. Yang diusulkan adalah indeks keintian, sebuah metode baru untuk menentukan tingkat keintian sebuah argumen. Bukti-bukti dari indeks keintian menunjukkan bahwa ada kontinuum tanpa sekat yang jelas antara kategori argumen inti dan oblik/non-inti, dan bahwa terdapat paralelisme yang menarik kalau tingkat keintitian dalam bahasa Indonesia dibandingkan dengan keintian bahasa Bali. Analisis yang berdasarkan indeks keintian ini memungkinkan kita untuk menentukan kentransitifan sintaksis dengan lebih pasti, sehingga bisa menjawab pemasalahan kentransitifan yang sebelumnya kontroversial untuk konstruksi-konstruksi tertentu yang melibatkan verba tanpa afiks dalam bahasa Indonesia. Dengan analisis ini, ada kemajuan pemahaman kita tentang sifat argumen (semi-)inti, ketransitifan sintaksis, kesimetrisan sistem diatesis, dan realisasi argumen alternatif, tidak hanya dalam bahasa Indonesia dan Bali, tetapi juga bahasa-bahasa Austronesia lain, yang berbeda secara tipologis, di Indonesia tengah/timur dan sekitarnya. Yang juga penting adalah studi indeks keintian ini bisa menjadi alat untuk analisis komparatif lintas bahasa terkait dengan pola konstruksi aplikatif yang tidak lazim, misalnya konstruksi aplikatif yang tidak melibatkan promosi ke argumen inti. Makalah ini juga membahas bagaimana sifat ketidakjelasan beda antara argumen inti dan oblik, terutama argumen yang
\end{abstract}


memperlihatkan semi-inti, menimbulkan tantangan tersendiri bagi teori tatabahasa yang mengharuskan argumen masuk dalam kotak kategori dengan sekat yang jelas.

Kata kunci: argumen inti, oblik, relasi grammatikal, Austronesia, diathesis, kesimetrisan

\section{Introduction}

The core-oblique distinction is surely one of the key distinctions in grammar. While the distinction is perhaps not universal, it is observed in many languages. The distinction is often important for language-internal reasons. For example, certain behavioural properties in Balinese and Indonesian (discussed in Section 3) are sensitive to the core-oblique distinction. The languages of eastern Indonesia, however, do not exhibit clear signs that a core-oblique distinction plays a role in their grammars. The core-oblique distinction is also important at the level of linguistic analysis and language description, particularly in relation to syntactic transitivity - a central topic in linguistics. One cannot talk about the syntactic transitivity of a structure without also talking about or assuming the core status of the argument(s) of the structure.

This paper explores syntactic transitivity and the core-oblique distinction in some Austronesian languages of Indonesia, focusing on the intermediate status between core and oblique categories. In particular, the commonly adopted conception that the core versus noncore classification is categorical is questioned. The categorical conception of the core-oblique distinction leads to the view that syntactic transitivity is also categorical. ${ }^{1}$ That is, an argument is typically considered to be either core or not. If a structure consists of two arguments and both are core, then the structure is syntactically transitive; or alternatively, if only one of them is core, then the structure is syntactically intransitive. Determining syntactic transitivity using the number of core arguments a verb has is not always easy in practice because the core status of an argument cannot always be easily determined to begin with. This is true even in languages that show clear morphosyntactic properties sensitive to a core-oblique distinction, such as Indonesian. This paper proposes a novel way to assess the core status of arguments.

The paper argues that there is empirical evidence for a cline running from syntactically core to non-core (oblique). A semi-core category is a legitimate class of arguments, at least in Indonesian. The existence of semi-core arguments poses a challenge to modern theories of grammars that pose discrete surface grammatical relations such as Lexical-Functional Grammar. It will also be argued that the foundation for coreness is essentially functional. It is motivated by the need to have a robust and productive system of encoding the most regular or frequently occurring participant-types. This accounts for the common properties of core arguments across languages; e.g., neutralisation of roles captured in terms of macro-roles in RRG (William A. Foley \& Van Valin, 1984; Van Valin \& LaPolla, 1997) or thematically unrestricted roles ([-r] feature) in LFG (Bresnan, 2001, among others; Bresnan \& Kanerva, 1989; Simpson, 1991) (see the list in Table 2). However, since languages differ with respect to the available coding resources and the extent of the grammaticalisation involved (i.e., how expressions of arguments and the properties are tied to other aspects in the grammars of specific languages), it is expected that actual batteries of diagnostic tests of coreness would vary across languages. Nevertheless, given the underlying common functional motivation, it is not surprising that some of them are similar. 
The paper is organised as follows. After defining core arguments (hereafter 'cores') and obliques in Section 2, Section 3 discusses the morphosyntactic properties of coreness in Balinese and Indonesian, showing that these languages demonstrate clear cases of core-oblique distinctions. It is also demonstrated that syntactic coreness is graded and that there are arguments with intermediate status between cores and obliques, classified as 'semi-core'. It will be demonstrated in this section that the proposed core-index analysis allows us to have a crosslinguistic comparative study of symmetricality of voice systems and that the symmetricality is also a matter of degree. Section 4 further discusses semi-coreness and the difficulty in drawing lines between cores and obliques/adjuncts in other Austronesian languages of central and eastern Indonesia. Section 5 discusses the theoretical implications of the present study. Directions for further research are given in Section 6.

\section{Definitions}

The terms 'core' and 'oblique' are often used without explicit definition. When a definition (with its representation) is given, it varies across theories, or across language descriptions. In what follows, different uses of the terms are briefly reviewed in subsection 2.1, followed by a description of the defining properties of core arguments in subsection 2.2 and a proposal to determine core status in 2.3 .

\subsection{Cores and obliques as classes of arguments}

Cores and obliques are classes of arguments. Core arguments are required syntactic units of a predicate, which in their simple cases refer to main participants of the state of affairs (SOA) ${ }^{2}$ expressed by the predicate. In language description within the so-called Basic Linguistic Theory (BLT) (R.M.W Dixon, 1979; R.M.W. Dixon, 1994; R.M.W. Dixon, 1997), cores are the required generalised syntactic-semantic functions abbreviated as A (i.e., the most actorlike/subject argument of a transitive verb), O (or P, as in Comrie (1978) (i.e., the most patientlike argument of a transitive predicate), and $\mathrm{S}$ (for the sole intransitive subject). A, S, and $\mathrm{O}$ are 'internal' (grammatical) functions with a special status, because they almost always have a variety of properties that set them off from most of the other grammatical functions (Andrews, 2007: 152).

In Dixon's BLT, the term 'oblique' is not used as a grammatical function label. The closest equivalent of oblique is what Dixon calls E. E stands for 'Extension to core', a non-A, non-O for an extended transitive, or a second obligatory argument in an extended intransitive (R.M.W. Dixon, 1994:122-3). E is, however, considered core by Dixon (2010: 116). For example, the goal argument of English give (to a beggar) as in (1)a and the theme argument ( $a$ prize) as in (1)b in are both $\mathrm{E}$; the clauses are both ditransitive with an $\mathrm{A}, \mathrm{O}, \mathrm{E}$ frame.

(1) a. John gave [his old coat] [to a beggar]

$$
\text { A O E }
$$

b. John gave [the winner] [a prize]

(R.M.W. Dixon, 2010: 134)

$$
\text { A } O \quad E
$$

Typologists (Comrie, 2005; Croft, 2003; Haspelmath, 2007; Margetts \& Austin, 2007, among others) also commonly use $\mathrm{G}$ (or R) and $\mathrm{T}$, where $\mathrm{G}$ and $\mathrm{T}$ are respectively the goal/beneficiary/recipient and theme of a trivalent predicate. For example, to a beggar in (1)a and the winner (1)b are G arguments, while his old coat in (1)a and a prize in (1)b are $\mathrm{T}$ 
arguments. $\mathrm{G}$ and $\mathrm{T}$ are respectively called 'ditransitive indirect object participant role cluster' and 'ditransitive direct object participant role cluster' by Croft (2003:143). ${ }^{3}$

The term 'ditransitive' in this paper, however, will be reserved for a trivalent structure where the A argument and the two other non-A arguments (i.e., $\mathrm{G}$ and $\mathrm{T}$ (or E)) are core arguments (i.e., 'being core' as defined in this paper; to be explicated in the ensuing subsections). I keep using $\mathrm{G}$, not $\mathrm{E}$, as a generalised semantic role representation. The precise core/oblique status of $\mathrm{G}$ is yet to be determined. It will be demonstrated later in section 3.1 that $\mathrm{G}$ can be grammatically core or non-core (i.e., oblique), and that $\mathrm{T}$ is the least core.

The abbreviation labels ${ }^{4}$ commonly used by typologists so far discussed are shown in (1). I found these labels useful and will keep using them for expository purposes.

(1) $\mathrm{S}=$ Sole argument of an intransitive predicate

$\mathrm{A}=$ Actor of a bivalent predicate

$\mathrm{P}=$ Patient of a bivalent predicate

$\mathrm{G}=$ Goal, recipient, or beneficiary of a trivalent predicate)

$\mathrm{T}=$ Theme of a trivalent predicate

In LFG, core (or term) arguments are defined as a class of syntactic arguments that belong to direct Grammatical Functions (GF) (Bresnan, 2001:96; Dalrymple, 2001). Core GFs include SUBJ, OBJ, and $\mathrm{OBJ}_{\theta}{ }^{5}$, in contrast to $\mathrm{OBL}\left(\right.$ ique)s, $(\mathrm{X}) \mathrm{COMP}\left(\right.$ lement clause)s, ${ }^{6}$ and ADJ(unct)s:

(2)

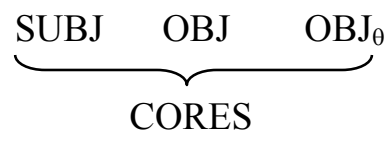

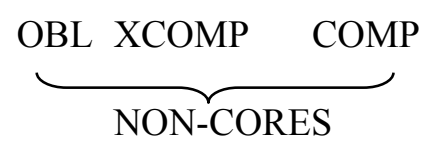

GFs in LFG are 'surface' functions and conventionally represented in capital letters (e.g., SUBJ). These GFs are distinct from underlying or logical relations, such as agent and patient, which are often called logical subject and object, respectively (represented in lower case). To avoid confusion in this paper, this convention is adopted when necessary. Thus, SUBJ is a surface subject relation whereas subject is an underlying agent-like relation.

In Role and Reference Grammar (William A. Foley \& Van Valin, 1984; Van Valin Jr. \& LaPolla, 1999:29), core arguments are arguments required by a (core) predicate. Core arguments in RRG are a class of arguments that include macro-role arguments (Actor and Undergoer, called direct core arguments) and oblique core arguments, which would be classified simply as OBLs in LFG. To avoid confusion, the term 'core' in this paper is reserved to refer to a direct core argument in RRG's sense.

To conclude, there is agreement across language descriptions/theories that core and oblique arguments are classes of syntactic units required by a predicate, distinct from peripheral units traditionally known as adjuncts. However, as noted, the term 'core' is used in slightly different ways. The terms core and oblique in this paper refer to two broad classes of arguments, representing two prototypical ends along a continuum with a semi-core class in between. The correspondence of the terms as used in this paper and the different labels of argument classes so far discussed can be shown in Table 1 . 
Table 1. Core vs. obliques and related argument labels

\begin{tabular}{|l|l|l|}
\hline In this paper: & \multicolumn{2}{|l|}{ 'core' 'semi-core' 'oblique' } \\
\hline BLT: Dixon (1994, 2010): & S, A, O, E & E \\
\hline $\begin{array}{l}\text { Croft (2003), Haspelmath (2007), } \\
\text { Margetts \& Austin (2007), and others }\end{array}$ & S, A, P, G/R, T & G/R \\
\hline LFG (Bresnan, 2001; Dalrymple, 2001) & SUBJ, OBJ, OBJ $\theta$ & OBL \\
\hline $\begin{array}{l}\text { RRG (William A. Foley \& Van Valin, } \\
\text { 1984; Van Valin \& LaPolla, 1997) }\end{array}$ & A,U (direct core) & oblique core \\
\hline
\end{tabular}

\subsection{Defining properties}

To be precise, the syntactic status of an argument (core, oblique, or not) will be approached using two complementary definitions in this paper: cross-linguistic and language-specific properties.

The cross-linguistic defining properties are shown in Table $2{ }^{7}$ While these properties are often not explicitly stated, they have been widely adopted in grammar description and linguistic theories. Properties (i)-(ii) are associated with the (surface) subcategorisation frame of a predicate: arguments are subcategorised for and are, therefore, usually obligatorily present in syntax. While subcategorised for, obliques are not always obligatory. Property (iii) says that if the units signify participants involved in the SOA expressed by the predicate, then they are arguments. Prototypical cores are associated with main participants whereas obliques are not. Note that a subcategorised argument is not necessarily associated with a (clear) participant of a SOA in the outside world (e.g., an expletive it SUBJ in English as in it rained). Property (iv) is associated with role assignment and identification/marking. Arguments are assigned semantic roles by the predicates: semantic roles of core arguments are directly assigned, whereas the semantic roles of OBLs are almost always assigned (or encoded) by a specific marker, which itself is determined by the head predicate. For example, the G role of the OBL beggar in (1) is assigned by the preposition to of the verb talk. Property (v) is the modification function, a property of adjuncts. Finally, property (vi) says that core arguments (SUBJ and OBJ) are thematically unrestricted, captured by the feature $-r$ (unrestricted) in the Lexical Mapping Theory of LFG (Bresnan, 2001, among others; Bresnan \& Kanerva, 1989; Simpson, 1991). This means that they are highly neutralised with respect to thematic roles; i.e., associated with a range of thematic roles or even none at all (e.g., an expletive or raised argument). Obliques, on the other hand, generally express specific roles and are marked for this accordingly.

Table 2. General characterisations of argument status (core, oblique and adjunct)

\begin{tabular}{|c|c|c|c|c|}
\hline & & \multicolumn{2}{|c|}{ ARGUMENT } & NON ARGUMENT \\
\hline & DEFINING PROPERTIES & CORE & OBLIQUE & ADJUNCT \\
\hline i. & Subcategorised for? & Yes & Yes & No \\
\hline ii & Obligatory? & Yes & Not always & No \\
\hline iii. & $\begin{array}{l}\text { Participant-related? } \\
\text { (a) main participant } \\
\text { (b) peripheral }\end{array}$ & $\begin{array}{l}\text { Yes } \\
\text { (b) }\end{array}$ & $\begin{array}{l}\text { Yes } \\
\text { (b) }\end{array}$ & No \\
\hline iv. & $\begin{array}{l}\text { Semantic role assigned } \\
\text { directly by the predicate? }\end{array}$ & Yes & No & No \\
\hline $\mathrm{v}$. & Modifying the predicate? & No & No & Yes \\
\hline
\end{tabular}




\begin{tabular}{|l|l|c|c|c|}
\hline vi. & Thematically generalised & Yes & No & No \\
\hline
\end{tabular}

The properties in Table 2, above, reflect the conceptual-functional foundation of coreness as part of grammatical system in expressing the most regular participant-types in expressing SOAs. Two participant-types are most commonly regularised, neutralised, abstracted, and (highly) grammaticalised in many languages; they become abstract elements of grammatical organization traditionally known as subject/object (i.e., cores). Such neutralisation is perhaps mainly due to economy; i.e., not explicitly encoding all specific semantic roles of the main participant(s) (and other participants of a SOA) when they are possibly inferred from the meaning of the verb.

The core properties are different but related to each other. Hence, properties (i) (subcategorisation) and (ii) (obligatoriness) are related and independent to each other, by which core and oblique status can be distinguished. Likewise, property (ii) ('obligatoriness') and property (iii) ('participant-relatedness') are two different but related properties associated with coreness. When combined, they give us an indication regarding the degree of coreness: a prototypical core argument (subject/A or object/P) is always obligatory because it corresponds to the main participant of a SOA; an Oblique is expected to be not always obligatory syntactically although it is required conceptually because it is not associated with a main participant; and adjuncts are almost always optional. Similarly, properties (iv) (rolemarking/assignment) and (vi) (thematic restrictedness/neutralisation) are closely related but not the same. When combined, they allow us to show degree of coreness. For example, a theme (T) of a three-place argument is thematically assigned by the verb (e.g., expressed as a bare NP) and hence core-like in accordance with property (iv). However, in Indonesian, for example, it is thematically restricted and oblique-like (in accordance with property (vi)) in that it is associated with a specific semantic role (i.e., theme) and does not alternate with subject in passivisation.

These properties are often useful as a first diagnostic tool for determining the status of a clausal unit, whether it is a core, an oblique, or an adjunct. Note that each property is a necessary, but insufficient, condition on its own (cf. Ross, 2002:28). For example, properties (i), (iii), and (v) single out not only cores, but also obliques. It is, therefore, necessary to check all of them, in conjunction with other language-specific properties, and establish the core status on a cumulative basis of satisfied relevant properties.

It is also clear from that table that the three categories have overlapping properties. For example, while obliques are often considered as arguments, they also share the properties of adjuncts shown by the shaded cells in Table 2 . The nature of the distinction of core, oblique, and adjunct as shown in the table can be represented in a schematic classification shown in Figure 1. The dotted vertical lines are intended to show that, if all relevant properties are taken into account, the distinctions between classes are not clear-cut.

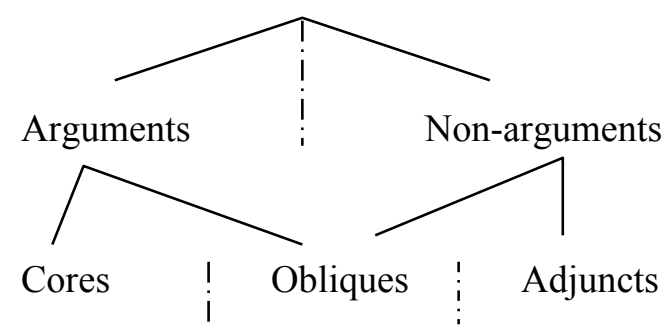

Figure 1. Classification of syntactic units 
To determine the core status of arguments with confidence, it is necessary to use a second approach, namely language-specific definitions, to further support and complement the analysis of the first approach. The language-specific definitions often make use of a set of diagnostic coding and behavioural properties that may differ from one language to another. Among the properties claimed to be associated with core arguments in different languages are agreement/cross-referencing (e.g., in Romance languages (A. Alsina, 1996); cf. Agreement Law of Relational Grammar (Frantz, 1981)), reflexive binding (e.g., in Albanian where only a core argument can bind a core reflexive (Sells, 1988); see also Balinese and Indonesian below), control (e.g., in Tagalog where only a core argument can be the controlee in the participial complement construction and only a core argument can be a controller in the participial adjunct construction (Kroeger 1993)), and nominalisation (e.g., in Korean and Japanese where different types of nominalizers are used for nominalized embedded clauses depending on whether they appear in core or oblique argument positions (Horie, 2000)).

The behavioural properties often require a deep understanding of the grammar of the language. For example, the distribution of quantifier float (QF) may vary across languages and even within the same language depending whether it is associated with a simple or complex quantifier. In Tagalog QF is a property of subject (P. Kroeger, 1993; Schachter, 1977), whereas in Balinese it is a property of core (Arka, 2003). (A complete list of core properties in Balinese is given below in Table 3.)

\subsection{Core index}

This paper proposes that core-oblique status be determined in terms of a core index calculated on the basis of the general/cross-linguistic and language-specific defining properties discussed in 2.2. The points and the implications of the proposal will be exemplified and discussed with reference to the study of Balinese (section 3.1.1) and Indonesian (sections 3.1.2, 4.1, and 4.2) two well-researched Austronesian languages with which I am most familiar-and other Austronesian languages of central/eastern Indonesia (Tukang Besi, Bima, Manggarai, Rongga, Taba and Alune) and Puyuma (an Austronesian language of Taiwan). I believe that this study is applicable to other languages.

The core index value ranges from 1.00 (definitely core) to 0.00 (definitely non-core). It is the proportion of core properties that are positively satisfied by the argument of a verb. It is calculated as follows. A score of 1 is given if the relevant property is satisfied by an argument; 0 if it is not satisfied; and 0.5 if it is partly satisfied. Thus, if there are 10 core properties identified in a given language and if an argument satisfies all of them, the argument is absolutely a core argument with an index of 1.00 (i.e., 10/10). In contrast, if none is satisfied, the argument is definitely an oblique with a core index of 0.00 (i.e., 0/10). This simple calculation of a core index will be used to determine and compare degrees of coreness/obliqueness of arguments (discussed in $3.2 \mathrm{ff}$ ). ${ }^{8}$

There are at least three advantages of using a core index. First, for a language-internal analysis, the index provides a useful tool to assess the core status of an argument. It, therefore, allows us to compare it with other arguments, which in turn allows us to assert the syntactic transitivity of a structure with confidence. 
Second, for cross-linguistic studies, while the exact defining properties for the core index may differ from one language to another, the core index makes it possible to have a rough comparison of coreness/obliqueness of arguments of similar structures across languages.

Third, related to the second point, research into core indices sheds light on broader linguistic issues. These include degree of symmetricality in voice systems particularly in Austronesian languages (briefly discussed in 3.2) and the role of distinct argument classes such as SUBJ/OBJ vs. OBL in language description and analysis (further discussed in section 5).

On the basis of calculated core index, it will be argued that there is no good evidence for categorical distinction between core and non-core and that an argument can have intermediate status (i.e., semi-core: neither a core nor an oblique). Therefore, I do not share the assertion that when an argument is not core it should then be classified as an oblique, or vice versa.

\section{Coreness in Balinese and Indonesian}

\subsection{Core properties and the core index}

Balinese and Indonesian show an explicitly defined distinction between cores and obliques. Cores in these languages are characterized by a number of language-specific morpho-syntactic properties in addition to the general defining properties shown in Table 2. Core properties in the two languages are now discussed in turn. In this subsection, I focus on the clear contrast of the core-oblique distinction. The borderline cases will be discussed in section 4 .

\subsubsection{Balinese}

There are at least fourteen properties by which we can identify core arguments in Balinese. They include general defining properties, such as obligatoriness and thematic generalisation, as well as language-specific properties in relation to quantifier float, topicalisation, depiction predicates, imperatives, binding, control, voice alternation, structural position, etc. (see Arka 2003 for detailed discussions); all are summarized in Table 3. Property 3 (categorical marking) is a language-specific strategy in relation to the general defining property given as property (iv) in Table 2. The left-most column shows the properties, and columns 1-7 show different types of arguments (A, P, G, etc.). The A argument appearing in three main voice types is examined: $\mathrm{A}_{\mathrm{AV}}, \mathrm{A}_{\mathrm{UV}}$, and $\mathrm{A}_{\mathrm{PASS}}$ refer to A of Actor Voice, A of Undergoer Voice and A of Passive Voice, respectively. As we shall see, A in these voice types is of different degrees of coreness. To be explicit, $\mathrm{G}$ of ditransitive verbs (i.e., where $\mathrm{G}$ is an object/core, typically in applicative verbs) is represented as $\mathrm{G}_{\mathrm{DTR}}$. Crucially, AV-UV/PASS alternations do not affect coreness of $\mathrm{G}_{\mathrm{DTR}}, \mathrm{P}$, and $\mathrm{T}$ in Balinese; hence these arguments are not subscripted with $\mathrm{AV}, \mathrm{UV}$, or PASS. The shaded cells show cases where the core properties are negative (i.e., not shared by the relevant arguments), partly satisfied, or not applicable. The core index of an argument is calculated and displayed in the last row of the table.

Table 3. Core properties in Balinese

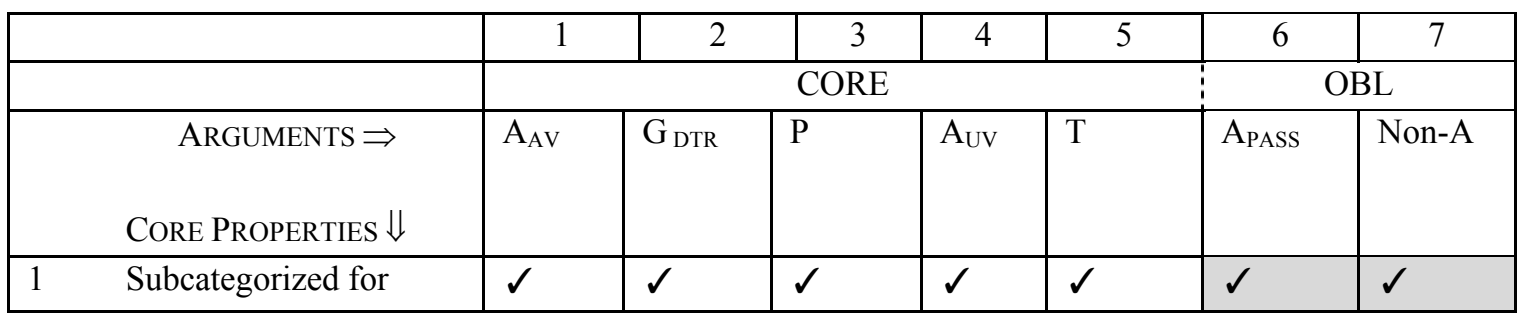




\begin{tabular}{|c|c|c|c|c|c|c|c|c|}
\hline 2 & Obligatory & $\sqrt{ }$ & $\sqrt{ }$ & $\sqrt{ }$ & $\checkmark$ & $\checkmark$ & * & * \\
\hline 3 & Categorical marking & $\begin{array}{l}\text { never } \\
\text { PP }\end{array}$ & $\begin{array}{l}\text { never } \\
\text { PP }\end{array}$ & $\begin{array}{l}\text { never } \\
\text { PP }\end{array}$ & $\begin{array}{l}\text { never } \\
\text { PP }\end{array}$ & $\begin{array}{l}\text { never } \\
\text { PP }\end{array}$ & PP & PP \\
\hline 4 & $\begin{array}{l}\text { Thematically } \\
\text { generalized }\end{array}$ & $\checkmark$ & $\checkmark$ & $\checkmark$ & $\checkmark$ & * & * & * \\
\hline 5 & QF with simple Qs & $\checkmark$ & $\checkmark$ & $\checkmark$ & * & $\checkmark$ & * & * \\
\hline 6 & QF with complex Qs & $\checkmark$ & $\checkmark$ & $\checkmark$ & $\checkmark$ & $\checkmark$ & $*$ & * \\
\hline 7 & $\begin{array}{l}\text { Topicalisation of } \\
\text { possessor phrase }\end{array}$ & $\checkmark$ & $\sqrt{ }$ & $\checkmark$ & n.a. & $\checkmark$ & * & * \\
\hline 8 & $\begin{array}{l}\text { Topicalisation with } \\
\text { resumptive pronoun }\end{array}$ & $\checkmark$ & $\sqrt{ }$ & $\checkmark$ & $\checkmark$ & $*$ & $*$ & * \\
\hline 9 & Depictive predicate & $\checkmark$ & $\checkmark$ & $\checkmark$ & * & $\checkmark$ & $*$ & $*$ \\
\hline 10 & $\begin{array}{l}\text { Elided (= zero) in } \\
\text { Imperative }\end{array}$ & $\checkmark$ & $\begin{array}{l}\checkmark \\
\text { (in UV } \\
\text { only) }\end{array}$ & $\begin{array}{l}\checkmark \\
\text { (in UV } \\
\text { only) }\end{array}$ & $\checkmark$ & $\begin{array}{l}\checkmark \\
\text { (in UV } \\
\text { only) }\end{array}$ & * & * \\
\hline 11 & $\begin{array}{l}\text { Binding: binder of a } \\
\text { core }\end{array}$ & $\checkmark$ & $\begin{array}{l}\checkmark \text { (for } \\
\mathrm{T} \text { only) }\end{array}$ & $*$ & $\checkmark$ & $*$ & * & $*$ \\
\hline 12 & $\begin{array}{l}\text { Control of complex } \\
\text { arguments }\end{array}$ & $\checkmark$ & $\boldsymbol{J}^{10}$ & $\checkmark$ & $\checkmark$ & n.a. & $*$ & * \\
\hline 13 & $\begin{array}{l}\text { Participation in AV-UV } \\
\text { alternation }\end{array}$ & $\checkmark$ & $\sqrt{ }$ & $\checkmark$ & $\checkmark$ & $\checkmark$ & * & * \\
\hline 14 & $\begin{array}{l}\text { Structural positions: } \\
\text { (a) fixed, A-position, } \\
\text { (b) not fixed, non-A } \\
\text { position }\end{array}$ & (a) & (a) & (a) & (a) & (a) & (b) & (b) \\
\hline & Core index: & $\begin{array}{l}14 / 14 \\
(1.00)\end{array}$ & $\begin{array}{l}13 / 14 \\
(0.92)\end{array}$ & $\begin{array}{l}12.5 / 14 \\
(0.89)\end{array}$ & $\begin{array}{l}11 / 14 \\
(0.78)\end{array}$ & $\begin{array}{l}9.5 / 14 \\
(0.67)\end{array}$ & $\begin{array}{l}1 / 14 \\
(0.07)\end{array}$ & $\begin{array}{l}1 / 14 \\
(0.07)\end{array}$ \\
\hline
\end{tabular}

The patterns shown in the table reveal the following points. First, there is a clear distinction of core status between the A argument of the agentive voice structure $\left(\mathrm{A}_{\mathrm{AV}}\right)$ and the A argument of the passive voice structure (APASS). All core properties are positive for $A_{A V}$ but are negative for $A_{\text {PASS }}$, except for the subcategorisation property. The sharp difference is reflected in the maximum core index of 1.00 (columns 1) vs. the lowest index of 0.07 (column 6) in the table.

The following examples illustrate the contrast of QF, which is restricted to a definite core argument in Balinese. The quantifier makejang 'all' can float; hence two readings are possible in (3)a, associated with $\mathrm{A}_{\mathrm{AV}}$ and $\mathrm{G}$. The T argument (buku) is indefinite and cannot launch QF. The ApAss (teken gurune) in (3)b cannot launch QF; hence only one reading is possible.

\section{(3) a. Guru-ne maang murid-e buku makejang teacher-DEF AV.give student-DEF book all A $\mathrm{G} \quad \mathrm{T}$}

(i) 'All the teachers gave the students books'

(ii) 'The teacher(s) gave all the students books'
b. Murid-e baang-a teken Guru-ne buku makejang student-DEF give-PASS by teacher-DEF book all G ApASS


(i) 'All the students were given books by the teacher(s)'

*(ii) 'The student(s) was/were given books by all the teachers'

Second, a non-A oblique is also like the A oblique in that it shares an extremely low core index of 0.07 . The following examples show evidence from topicalisation of possessor phrase, which is also a core property in Balinese. The possessive pronoun -ne is associated with the topicalized NP Nyoman. It is acceptable in (4)a and (4)b where the possessor is part of goal object and subject respectively. The acceptability is downgraded when it is associated with an Oblique marked by sig, (4)c.

(4) a. Nyoman, cang manteg umah-ne teken batu Nyoman 1 AV.pelt house-3POSS with stone A P Inst

'As for Nyoman, I pelted his house with stones'

b. Nyoman, umah-ne panteg cang teken batu

Nyoman house-3POSS UV.pelt1 with stone

$\mathrm{P} \quad \mathrm{A}$ Inst

'As for Nyoman, I pelted his house with stones.'

c. ?* Nyoman, cang manteg-ang batu sig umah-ne

Nyoman 1 AV.pel-APPL stone to house-3POSS

A $\quad \mathrm{T} \quad \mathrm{G}$

'As for Nyoman, I threw stones at his house.'

Third, certain core properties listed in the table may not be applicable to all core arguments. There may be some qualification. Limitation of space precludes a full discussion of these issues; I refer the reader to Arka (2003: chapter 3). In what follows, I discuss only two of them (argument elision in imperatives and binding of core reflexive).

The core property of elision in the imperative structure (property 10 in the table) applies to A, but only partly to G, P, and T. Thus, A is elided in the imperative UV and AV structures (5)a-b. (The elided argument is represented as a $\varnothing$ with its subscripted role, e.g., $\varnothing_{A}=$ elided A.) Note that Balinese imperatives cannot appear in passive form; i.e., the elided oblique ApAss is unacceptable as seen in (5)d-e. G, P, and T in the imperative structure can be elided only in the UV verb; hence the contrast between (6)a and (6)b.

(5)
a. $\varnothing_{\mathrm{P}}$ Jemak $\varnothing_{\mathrm{A}}$ !
UV.take
b. $\varnothing_{A}$
Nyemak nasi ma!
AV.take rice PART
'Take it!'
'Take some rice, please!'
c. *Nyemak
d.* emak-a (teken cai)
take-PASS (by 2
e. * ka-jemak!
PASS-take

(6) a. $\varnothing_{G}$ Jemak-ang $\varnothing_{A} \varnothing_{T}$ !

UV.take-APPL

'Take (it) (for him/her/them)'

b. *Nyemak-ang!

AV.take-APPL

The binder of a core reflexive in Balinese must be itself a core argument. ${ }^{11}$ However, this only applies to a core argument that is thematically more prominent than the bindee in a given 
argument structure. This kind of constraint is also observed in other languages (Dalrymple, 1993; Manning, 1996; Sells, 1988). Hence, this applies to $A_{A V}, G$, and $A_{U V}$, not to the least core (P or T). For example, the reflexive T ragane is bound by G OBJ in (7)a or G SUBJ in (7)b. Sentence (7)c is unacceptable because the T argument ida cannot bind the reflexive G.

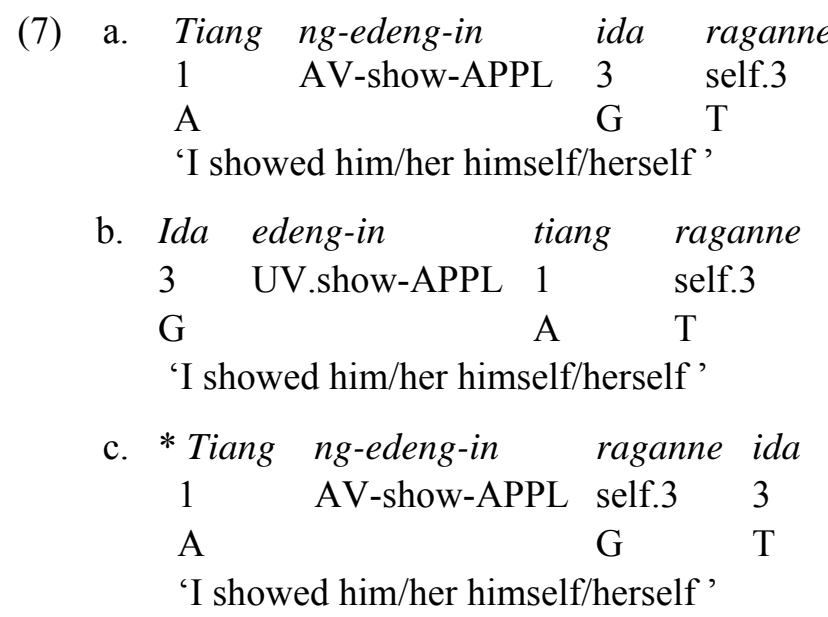

To conclude, $\mathrm{A}, \mathrm{G}, \mathrm{P}$, and $\mathrm{T}$ are core arguments whose membership as a class distinct from obliques in Balinese is supported by the study of core indices. First, as a class, their indices are 0.67 and over. Second, there is a sharp difference of core index between them and obliques; i.e., between the least core $\mathrm{T}(0.67)$ and Apass $(0.07)$. Third, the study of core indices in this paper also provides evidence of thematically based prominence among core arguments (Arka, 2003; Manning, 1996). The prominence reflects the hierarchy already known in the literature of linguistic typology (Keenan and Comrie (1977)) and theoretical linguistics, e.g., Relational Hierarchy in Relational Grammar (Bell, 1983), Obliqueness Hierarchy in HPSG (Pollard \& Sag, 1994), and functional hierarchy in LFG (Bresnan, 2001; Dalrymple, 2001). Importantly, the study in this paper reveals 'surprises' in studies of argument prominence: (i) $P$ is more core/prominent than $\mathrm{T}^{12}$, and (ii) $\mathrm{A}_{\mathrm{AV}}$ and $\mathrm{A}_{\mathrm{UV}}$ are in fact not of equal prominence. ${ }^{13}$ The issue of prominence will be further discussed in section 3.2.

\subsubsection{Indonesian}

Core properties in Indonesian (adapted from Arka and Manning (2008) (but see also Vamarasi (1999) and Musgrave $(2001 ; 2008)$ are displayed in Table 4. They include general and languagespecific properties ( $\mathrm{QF}$, topicalisation, binding, etc.) that are essentially similar to core properties in Balinese. ${ }^{14}$ In this subsection, I discuss important points showing similarities/ differences between Indonesian and Balinese as regards to their core properties.

Table 4. Core properties in Indonesian

\begin{tabular}{|c|c|c|c|c|c|c|c|}
\hline & 1 & 2 & 3 & 4 & 5 & 6 & 7 \\
\hline & \multicolumn{5}{|c|}{ CORE } & \multicolumn{2}{|c|}{ OBL } \\
\hline $\begin{array}{l}\text { CORE ARGUMENTS } \\
\text { PROPERTIES }\end{array}$ & $\mathrm{A}_{\mathrm{AV}}$ & G & $\mathrm{P}$ & $\mathrm{A}_{\mathrm{UV}}$ & $\mathrm{T}$ & A A $_{\text {PSS }}$ & Non-A \\
\hline $\begin{array}{ll}1 & \text { Subcategorized for }\end{array}$ & $\sqrt{ }$ & $\sqrt{ }$ & $\sqrt{ }$ & $\sqrt{ }$ & $\sqrt{ }$ & $\sqrt{ }$ & $\checkmark$ \\
\hline 2 Obligatory & $\checkmark$ & $\checkmark$ & $\checkmark$ & $\checkmark$ & $\checkmark$ & $*$ & * \\
\hline
\end{tabular}




\begin{tabular}{|c|c|c|c|c|c|c|c|c|c|}
\hline 3 & \multicolumn{2}{|l|}{ Categorical marking } & \multicolumn{2}{|c|}{\begin{tabular}{|l} 
never \\
PP
\end{tabular}} & $\begin{array}{l}\text { never } \\
\text { PP }\end{array}$ & $\begin{array}{l}\text { never } \\
\text { PP }\end{array}$ & $\begin{array}{l}\text { never } \\
\text { PP }\end{array}$ & $\begin{array}{l}\mathrm{PP} / \\
\mathrm{NP}\end{array}$ & $\mathrm{PP}$ \\
\hline 4. & \multicolumn{2}{|c|}{ Thematically generalized } & \multicolumn{2}{|l|}{$\checkmark$} & $\checkmark$ & $\sqrt{ }$ & $*$ & * & $*$ \\
\hline 5 & \multicolumn{2}{|l|}{ QF with semua 'all' } & \multicolumn{2}{|l|}{$\checkmark$} & $\checkmark$ & * & $\checkmark$ & * & * \\
\hline 6 & \multicolumn{2}{|l|}{$\begin{array}{l}\text { Topicalisation of } \\
\text { possessor phrase }\end{array}$} & \multicolumn{2}{|l|}{$\checkmark$} & $\checkmark$ & n.a. & $\checkmark$ & * & $*$ \\
\hline 7 & \multicolumn{2}{|l|}{$\begin{array}{l}\text { Topicalisation with a } \\
\text { resumptive pronoun }\end{array}$} & \multicolumn{2}{|l|}{$\checkmark$} & $\checkmark$ & $\checkmark$ & $*$ & * & $*$ \\
\hline 8 & Depictive predicate & \multicolumn{2}{|l|}{$\checkmark$} & $\checkmark$ & $\checkmark$ & * & $\checkmark$ & * & $*$ \\
\hline 9 & $\begin{array}{l}\text { Elided (= zero) in } \\
\text { Imperative }\end{array}$ & \multicolumn{2}{|l|}{$\checkmark$} & $\begin{array}{l}\checkmark \\
\text { (in UV } \\
\text { only) }\end{array}$ & $\begin{array}{l}\checkmark \\
\text { (in UV } \\
\text { only) }\end{array}$ & $\checkmark$ & $\begin{array}{l}\checkmark \\
\text { (in } \\
\text { UV } \\
\text { only) }\end{array}$ & $*^{15}$ & n.a. \\
\hline 10 & $\begin{array}{l}\text { Binding: binder of a } \\
\text { core }\end{array}$ & \multicolumn{2}{|l|}{$\checkmark$} & $\begin{array}{l}\checkmark \text { (for } \\
\mathrm{T} \text { only) }\end{array}$ & $*$ & $\begin{array}{l}\checkmark \\
\text { (for } \\
\text { refl.) }\end{array}$ & $*$ & $*$ & $*$ \\
\hline 11 & $\begin{array}{l}\text { Participation in } \\
\text { AV/UV alternation }\end{array}$ & \multicolumn{2}{|l|}{$\checkmark$} & $\checkmark$ & $\checkmark$ & $\checkmark$ & $*$ & $*$ & $*$ \\
\hline 12 & $\begin{array}{l}\text { Proclitic on the } \\
\text { verb }\end{array}$ & \multicolumn{2}{|c|}{$\begin{array}{l}\checkmark \\
(\text { for } \\
\mathrm{ku}=)\end{array}$} & $\checkmark$ & $\sqrt{ }$ & $\checkmark$ & $*$ & $*$ & $*$ \\
\hline 13 & $\begin{array}{l}\text { Structural positions: } \\
\text { (a) fixed, A- } \\
\text { position, } \\
\text { (b) not fixed, non-A } \\
\text { position }\end{array}$ & \multicolumn{2}{|l|}{ (a) } & (a) & (a) & (a) & (a) & (a)/(b) & (b) \\
\hline & Core index & \multicolumn{2}{|c|}{$\begin{array}{l}13 / 13 \\
(1.00)\end{array}$} & $\begin{array}{l}12.5 / 13 \\
(0.96)\end{array}$ & $\begin{array}{l}11.5 / 13 \\
(0.88)\end{array}$ & $\begin{array}{l}10 / 13 \\
(0.76)\end{array}$ & $\begin{array}{l}7.5 / 1 \\
3 \\
(0.57)\end{array}$ & $\begin{array}{l}2 / 13 \\
(0.15)\end{array}$ & $\begin{array}{l}1 / 13 \\
(0.07)\end{array}$ \\
\hline
\end{tabular}

The first point to note is that the core index in Indonesian, as in Balinese, shows good evidence of contrast between core and non-core arguments with $\mathrm{A}_{\mathrm{AV}}$ being the absolute core (i.e., with an index of 1.00). The pattern shows a wide gap between the indices of the prototypical core and oblique arguments: $\mathrm{A}_{\mathrm{AV}} / \mathrm{G} / \mathrm{P}$ of $1.00-0.88$ vs. Non-A oblique of 0.07 . The properties that make Indonesian obliques look less oblique than the Balinese ones are two properties of ApASs in Indonesian: i) the expression of APASS (possibly in NP as well as PP) and ii) its structural position if it is an NP that must be immediately postverbal. The following are the relevant examples: the agent Ayah can appear as an NP (8)a or a PP (8)b.

(8) a. Amir di-perlihatkan Ayah foto dirinya (Arka \& Manning 2008) Amir di-show father picture self.3

'Amir ${ }_{i}$ was shown the picture of himself $\mathrm{i}_{\mathrm{i} / *_{\mathrm{j}}}$ by father ${ }_{\mathrm{j}}$.'

b. Amir di-perlihatkan foto dirinya oleh Ayah.

Amir di-show picture self.3 by father

'Amir ${ }_{\mathrm{i}}$ was shown the picture of himself $\mathrm{i}_{\mathrm{i} / \mathrm{j}}$ by father ${ }_{\mathrm{j}}$.'

c. * Amir diperlihatkan foto dirinya Ayah. 
The Apass ayah 'father' is certainly oblique-like in other respects. For example, in reflexive binding, the A AASS cannot bind the reflexive dirinya; i.e., only one reading in (8)a, with $* \mathrm{j}$ not possible. In contrast, the $\mathrm{A}_{\mathrm{Av}}$, ayah, as seen in (9), can be the antecedent of dirinya; hence there is an ambiguous reading for this sentence.

(9) Ayah mem-perlihatkan Amir foto dirinya.

father AV-show Amir picture self.3

'Father showed Amir $_{i}$ the picture of himself $\mathrm{i}_{\mathrm{j} j \mathrm{j}}$.'

In addition, the $A_{\text {PASS }} \mathrm{NP}$ is optional and cannot be associated with a depictive predicate. Compare the sentence in AV (10)a with its corresponding passive in (10). Note that the actor, Ayah 'father', can be associated with the depictive predicate 'naked' only when it is $A_{A V}$, (10)a. Thus, (10)a is ambiguous because the object Amir can also be the argument of the depictive predicate. The passive counterpart (10)b, in contrast, is not ambiguous because reading (ii) is unacceptable.

\section{(10) a. Ayah menuntun Amir ke kamar telanjang} father AV.lead Amir to room naked i) Father led Amir to the room, and father was naked. ii) Father led Amir to the room, and Amir was naked.

b. Amir di-tuntun (Ayah) ke kamar telanjang (A PASS $_{\text {is optional) }}$ Amir PASS-lead father to room naked

i) Amir was led to the room (by father), and Amir was naked.

ii) * Amir was led to the room by father, and father was naked.

However, while $\mathrm{T}$ is the least core, both in Indonesian and Balinese, $\mathrm{T}$ in Indonesian is more oblique-like than its corresponding $\mathrm{T}$ in Balinese. Indonesian $\mathrm{T}$ behaves like an oblique in that it does not participate in AV/UV alternation. Evidence for this comes from AV/UV alternation. It is a property of prototypical cores in Indonesian, whereas the AV/UV also applies to a non-prototypical core in Balinese.

First, consider the AV/UV alternation in Indonesian, exemplified in (11):

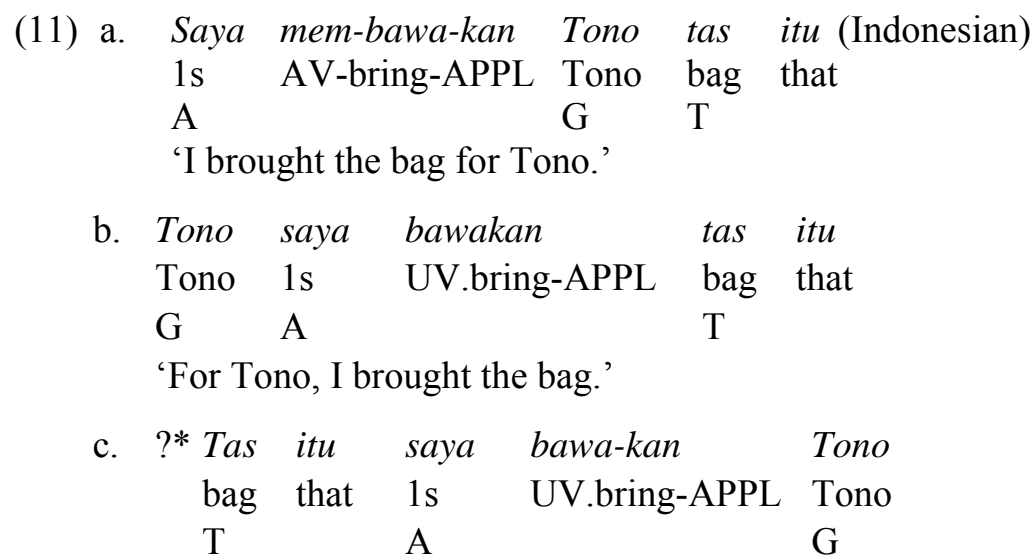

In the AV structure (11)a, saya is the object $(\mathrm{G})$ and tas itu is the second object (T). The $\mathrm{G}$ argument Tono can alternate to become a SUBJ appearing sentence-initially in the UV structure (11)b. This is not possible for the T argument tas itu; i.e., (11)c is unacceptable.

Balinese T, as seen in (12), however, can participate in AV/UV alternation, even though it is (like Indonesian $\mathrm{T}$ ) the least core. Balinese is not unique in allowing both $\mathrm{T}$ and $\mathrm{G}$ objects to 
alternate with SUBJ in voice alternations. Kichaga is also reported to have a similar 'symmetrical' object property where both OBJs of ditransitive verbs behave alike in passivisation (Bresnan \& Moshi, 1990). ${ }^{16}$
(12) a. Tiang ngaba-ang Nyoman kompek. (Balinese)
1 AV.bring-APPL name bag
'I brought a bag for Nyoman.'

b. Nyoman abaang tiang kompek.

Nyoman UV.bring 1 bag

'For Nyoman, I brought a bag.'

$\begin{array}{lrlll}\text { c. Kompek nto abaang tiang Nyoman. } & \text { Nyoman }\end{array}$

'The bag, I brought it for Nyoman.'

An oblique does not participate in AV/UV alternation in both Indonesian and Balinese. To do so, it must be first promoted to core by means of applicativisation. (This applies both in Indonesian and Balinese but not in other Austronesian languages of Indonesia; see unusual cases of applicativisation and core promotion in sections 4.3.2-3.) For example, Tono in (13)a below is an Oblique, which is obligatorily marked by the preposition untuk. Without the preposition, the sentence is unacceptable (13)b. This oblique G argument does not participate in the UV alternation; hence (13)c is unacceptable.

(13) a. Sayamem-bawa tas itu untuk Tono
1s AV-bring bag that for Tono
'I brought the bag for Tono.'
b. * Saya mem-bawa tas itu Tono.
$1 \mathrm{~s}$ AV-brng bag that Tono

FOR: 'I brought the bag for Tono.'

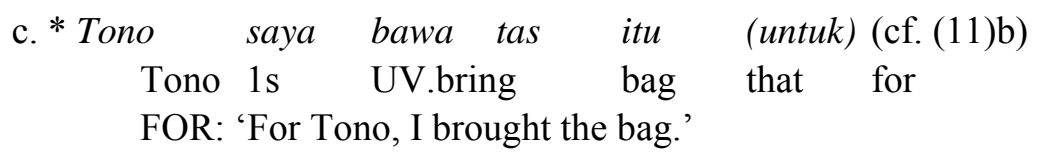

The study of core index in Indonesian also reveals that A, G, P, and T are not of equal degree of coreness. Importantly, the relative degree of coreness shows striking parallelism with that in Balinese. The parallelism $\left(\mathrm{A}_{\mathrm{AV}}>\mathrm{G}_{\mathrm{DTR}}>\mathrm{P}>\mathrm{A}_{\mathrm{UV}}>\mathrm{T}\right)$ is shown in Table 5 below. Prominence is further discussed in section 3.2.

Table 5. Core indices of Balinese and Indonesian compared

\begin{tabular}{|c|c|c|c|c|c|c|c|c|}
\hline & & \multicolumn{5}{|c|}{ CORE } & \multicolumn{2}{|c|}{ OBL } \\
\hline & & $\mathrm{A}_{\mathrm{AV}}$ & $\overline{\mathrm{G}_{\mathrm{DTR}}}$ & $P$ & $\overline{A_{U V}}$ & $\mathrm{~T}_{\mathrm{DTR}}$ & $\overline{A_{P A S S}}$ & Non-A \\
\hline \multirow{2}{*}{$\begin{array}{l}\text { Core } \\
\text { indices }\end{array}$} & Balinese & $\begin{array}{l}14 / 14 \\
(1.00)\end{array}$ & $\begin{array}{l}13 / 14 \\
(0.92)\end{array}$ & $\begin{array}{l}12.5 / 14 \\
(0.89)\end{array}$ & $\begin{array}{l}11 / 14 \\
(0.78)\end{array}$ & $\begin{array}{l}9.5 / 14 \\
(0.67)\end{array}$ & $\begin{array}{l}1 / 14 \\
(0.07)\end{array}$ & $\begin{array}{l}1 / 14 \\
(0.07)\end{array}$ \\
\hline & Indonesian & $\begin{array}{l}13 / 13 \\
(1.00)\end{array}$ & $\begin{array}{l}12.5 / 13 \\
(0.96)\end{array}$ & $\begin{array}{l}11.5 / 13 \\
(0.88)\end{array}$ & $\begin{array}{l}10 / 13 \\
(0.76)\end{array}$ & $\begin{array}{l}7.5 / 13 \\
(0.57)\end{array}$ & $\begin{array}{l}2 / 13 \\
(0.15)\end{array}$ & $\begin{array}{l}1 / 13 \\
(0.07)\end{array}$ \\
\hline
\end{tabular}




\begin{tabular}{l|l|l|l|l|l|l|} 
Ranking: & 1 & 2 & 3 & 4 & 5 & 6
\end{tabular}

The relative prominence correlates with the different degrees of sharing ('full', 'partial', and 'absent') of certain core properties by non- $\mathrm{A}_{\mathrm{AV}}$ arguments. The failure to fully or partially share core properties is a complex matter. It may be a general constraint of the grammar of the language. For example, as seen in the preceding examples (11)-(12), Balinese grammar is different from Indonesian in that Balinese allows both $G$ and $T$ in ditransitive structure to participate in AV/UV alternation, showing a sign of symmetry of double objects. ${ }^{17}$

The failure may also be due to constraint interaction, e.g., definiteness in information structure. For instance, in a ditransitive AV structure, A and G are generally definite, whereas $\mathrm{T}$ is typically indefinite. Then, quantifier float (which requires a definite reference) is always acceptable for A and G, but not so for T. I would say that quantifier float is still operative for the coreness of $\mathrm{T}$, but it just happens to be blocked by definiteness, a property of information structure, which is strictly speaking non-syntactic. For this reason, I put a tick $(\checkmark)$ in the relevant cell for $\mathrm{T}$ in the table.

Finally, core properties are sometimes interrelated with each other and inseparable from semantic or grammatical subject properties. For example, for the AV/UV alternation property, the AV transitive structure simultaneously picks up the properties of an argument being a core, an actor, and the surface subject/pivot while at the same time G/P is selected as a non-A core OBJ.

Another instance is, as noted earlier (examples (7) for Balinese and (8)-(9) for Indonesian), the reflexive binding property. It may require the binder argument to be a core that is thematically superior to the bindee, otherwise reflexive binding fails.

\subsection{Prominence and degree of coreness}

There are logically at least three ways to rank arguments: (i) ranking based on 'surface' grammatical relations (i.e., grammatical subject>non-subjects), (ii) ranking based on 'semantic' role prominence (i.e., Actor $>$ non-Actor), and (iii) ranking based on coreness of the arguments (e.g., cores $>$ non-cores). Discussing all of these rankings in detail, their interrelationship, and their significance in the grammar of a language, or in grammars across languages, is beyond the scope of the present paper. In this section, I mainly focus on ranking method (iii), articulating the significance of the index-based argument prominence (briefly mentioned earlier in sections 3.1.1 and 3.1.2) in syntactic transitivity, symmetricality of voice systems, and the typology of arguments along the core-oblique continuum.

The claim I want to make is that syntactic transitivity is graded if viewed in terms of core index. As seen in Table 5, the two rankings of coreness of arguments in Balinese and Indonesian show striking parallelism. The following two points are worth noting in this respect: i) the cutoff point between core and non-core classes and ii) the degree of coreness within the core group.

The cut-off point of the core class in both languages differs slightly. The second object of a ditransitive structure ( $\mathrm{T}$ ), which has been often classified as a core argument in the literature, shows an index of 0.57 (Indonesian) and 0.67 (Balinese). Indonesian $\mathrm{T}$ is, therefore, less core than its Balinese T counterpart. In contrast, prototypical obliques have an extremely low core index, as low as 0.07 (with the only core-like property coming from subcategorisation). Thus, there is a large gap between a prototypical oblique and even the least core (T). 
Given the index range of 1.00-0.00, I will classify an argument with a mid-range core index (i.e., around 0.50) as 'semi-core'. This is an argument with intermediate status; it is not really a core, but it is not an oblique either. ${ }^{18}$ To be precise, I propose the term 'semi-core' as part of a five-way ${ }^{19}$ general classification of arguments from 'prototypical core' to 'prototypical oblique'. The classification is shown in (14). The arrow in (14) indicates ascending/descending degree of coreness/obliqueness.

$$
\begin{aligned}
& \text { Core index: Types of coreness/obliqueness: } \\
& \text { 0.80-1.00 1: } \quad \text { Prototypical Core } \\
& 0.60-0.79 \text { 2: } \quad \text { Marginal Core } \\
& \text { 0.40-0.59 3: } \quad \text { Semi Core } \\
& \text { 0.20-0.39 4: \ Marginal Oblique } \\
& \text { 0.00-0.19 5: } \quad \text { Prototypical Oblique }
\end{aligned}
$$

Research on arguments as reported in the literature often focuses on prominent or prototypical cores A, G, and P. Overlooked is the study of arguments having a core index of less than 0.50, classified here as semi-core here. This is an interesting field of investigation. What kind of verbs/structures are these arguments associated with? This is the topic of section 4 .

Having established argument classes along the core-oblique continuum as shown in (14), we can now discuss the degree of coreness further, highlighting its significance in wider (typological) context of symmetricality in voice systems.

It has been pointed out earlier that $\mathrm{A}, \mathrm{G}_{\mathrm{DTR}}, \mathrm{P}$, and $\mathrm{T}$ are often considered core arguments and that there is evidence from their core indices that they have different degrees of coreness. As seen from Table 5, the $A_{A V}$ argument is the most core, and $T$ is the least core in both languages. In between, in descending order, are $\mathrm{G}_{\mathrm{DTR}}, \mathrm{P}$, and $\mathrm{A}_{\mathrm{Uv}}$.

It is widely accepted that $\mathrm{A}$ and $\mathrm{P}$ are typically encoded as core arguments of transitive verbs. Our present core-index study confirms this, showing that $\mathrm{A}_{\mathrm{AV}}$ and $\mathrm{P}$ in Balinese and Indonesian have a core index of over 0.80. Importantly, the present study also reveals that $\mathrm{G}_{\mathrm{DTR}}$ in these two languages is prototypically more core than P. For example, $\mathrm{G}_{\mathrm{DTR}}$ in Indonesian has a core index of 0.92 whereas $\mathrm{P}$ has an index of 0.89 . Indonesian $\mathrm{T}$, however, turns out to be semi-core (i.e. core index of 0.57 ), whereas Balinese $\mathrm{T}$ is marginally core.

\subsection{Symmetricality of voice systems}

The core index study has an important implication on the typological study of voice system, in particular the conception of its symmetricality. A 'symmetrical' voice system (Arka, 2003; William A Foley, 1998, 2008) is one in which main core arguments (A, P) are equally possibly selected as syntactic Subject/Pivot without obligatory demotion of either of them into oblique status (as is the case in the asymmetrical voice system), and any voice selection is also equally marked (Himmelmann, 2005). Thus, the claim is that voice alternations in the symmetrical system, e.g., a change of AV to UV, may not change transitivity of the structure. Given the core index analysis, we are now able to assess this claim further.

It has been demonstrated in the preceding section that the core index analysis allows us to insightfully compare degrees of coreness, not only between different arguments (A, P, etc.) within the same language, but also between similar arguments in different languages (e.g., $\mathrm{T}$ in Balinese vs. $\mathrm{T}$ in Indonesian). Importantly, the core index study also makes it possible to precisely uncover differences and similarities of voice systems across languages. Such differences/similarities might have been overlooked or undetectable in earlier studies of 
Austronesian linguistics due to lack of good methodology. The finding, in turn, allows us to rethink the notion of symmetricality in voice systems. Viewed in terms of core index analysis, I wish to claim that languages should not simply be categorically classified as symmetrical vs. non-symmetrical, but rather as having degrees of symmetricality (i.e., a cline from highly symmetrical, to less symmetrical, to highly asymmetrical).

To illustrate the points, in what follows, Balinese and Indonesian are comparatively discussed in relation to Puyuma (an Austronesian language of Taiwan). Puyuma is chosen because it is one of the Austronesian languages outside Indonesia that is now well studied (Ross, 2006; Teng, 2005, 2008). Puyuma shows interesting but slightly different characteristics from Balinese/Indonesian in terms of its verbal voice morphology and dependent marking. ${ }^{20}$

Puyuma (Ross, 2006; Teng, 2005, 2008) is verb-initial, showing AV and UV voice types with the UV can be further subclassified into different UV types, e.g., $\mathrm{UV}_{1}$ (equivalent to PF (Patient Focus)). Each voice type has a distinct verbal voice marking. Examples showing the AV-UV ${ }_{1}$ alternation in Puyuma are shown in (15). In the AV structure (15)a, the A Isaw is syntactic subject/pivot, and its $\mathrm{P}$ (i.e., $\mathrm{P}_{\mathrm{AV}}$ ) 'money' in (15)a is obliquely marked and not pronominally cross-referenced on the verb. In the UV counterpart (15)b, the $\mathrm{P}_{\mathrm{UV}}$ is a syntactic subject. It receives the NOM phrasal marker na. It is also pronominally cross-referenced on the verb by a zero enclitic, not shown in (15).
(15) a. T<em>akaw Da paisu i isaw $<\mathrm{AV}>$ steal obl:id money NOM:PS Isaw
'Isaw stole money.'
b. tu=Takaw-aw na paisu kan isaw
GEN:3s=steal-UV ${ }_{1}$ NOM:D money OBL:PS Isaw
'Isaw stole the money.'

On the basis of the descriptions of Puyuma, we can identify core properties and calculate core indices of arguments in this language. The finding is shown in Table 6 . As seen, $\mathrm{S} / \mathrm{A} / \mathrm{P}_{\mathrm{Uv}}$ are definitely core arguments with the maximum core index of 1.00 in this language, whereas a non$\mathrm{A}$ argument in the AV structure, e.g., $\mathrm{LOC}_{\mathrm{AV}}$ is definitely not a typical core argument. This will be further discussed in relation to Balinese and Indonesian below. For simplicity, we will ignore Guv.

\begin{tabular}{|c|l|c|c|c|c|c|c|}
\hline & & \multicolumn{3}{|c|}{ CORE ------------------ OBL } \\
\hline \multirow{2}{*}{1} & PROPERTIES & 1 & 2 & 3 & 4 & 5 & 6 \\
\cline { 2 - 8 } & S & $\mathrm{A}_{\mathrm{AV}}$ & $\mathrm{P}_{\mathrm{UV}}$ & $\mathrm{A}_{\mathrm{UV}}$ & $\mathrm{P}_{\mathrm{AV}}$ & LOC $_{\mathrm{AV}}$ \\
\hline 2 & Obligatory & $\mathrm{Y}$ & $\mathrm{Y}$ & $\mathrm{Y}$ & $\mathrm{Y}$ & $\mathrm{Y}$ & $\mathrm{N}$ \\
\hline 3 & $\begin{array}{l}\text { Participant-related: } \\
\text { main }\end{array}$ & $\mathrm{Y}$ & $\mathrm{Y}$ & $\mathrm{Y}$ & $\mathrm{Y}$ & $\mathrm{Y}$ & $\mathrm{N}$ \\
\hline 4 & $\begin{array}{l}\text { Registered on the verb } \\
\text { by voice/verbal } \\
\text { morphology }\end{array}$ & $\mathrm{Y}$ & $\begin{array}{c}\mathrm{Y} \\
(<\mathrm{em}>\end{array}$ & $\mathrm{Y}$ & $\mathrm{N}$ & $\mathrm{N}$ & $\mathrm{N}$ \\
\hline 5 & $\begin{array}{l}\text { Thematically } \\
\text { unrestricted }\end{array}$ & $\mathrm{Y}$ & $\mathrm{Y}$ & $\mathrm{Y}$ & $\mathrm{Y}$ & $\mathrm{Y}$ & $\mathrm{N}$ \\
\hline 6 & Phrasal marking & NOM: & NOM: & NOM: & OBL: & OBL: & OBL: \\
\hline
\end{tabular}




\begin{tabular}{|l|l|c|c|c|c|c|c|}
\hline & & $\begin{array}{c}\mathrm{i} / \mathrm{na} / \\
\mathrm{a}\end{array}$ & $\begin{array}{c}\mathrm{i} / \mathrm{na} / \\
\mathrm{a}\end{array}$ & $\begin{array}{c}\mathrm{i} / \mathrm{na} / \\
\mathrm{a}\end{array}$ & $\begin{array}{c}\mathrm{kana} / \\
\mathrm{kan} / \mathrm{Da}\end{array}$ & $\begin{array}{c}\mathrm{kana} / \\
\mathrm{kan} / \mathrm{Da}\end{array}$ & $\mathrm{i}$ \\
\hline 7 & $\begin{array}{l}\text { Bound pronominal on } \\
\text { the verb }\end{array}$ & $\begin{array}{c}\mathrm{Y}: \\
\mathrm{NOM}\end{array}$ & $\begin{array}{c}\mathrm{Y}: \\
\mathrm{NOM}\end{array}$ & $\begin{array}{c}\mathrm{Y}: \\
\mathrm{NOM}\end{array}$ & $\begin{array}{c}\mathrm{Y}: \\
\mathrm{GEN}\end{array}$ & $\mathrm{N}$ & $\mathrm{N}$ \\
\hline 8 & cross-referencing & $\mathrm{Y}$ & $\mathrm{Y}$ & $\mathrm{Y}$ & $\mathrm{Y}$ & $\mathrm{N}$ & $\mathrm{N}$ \\
\hline 9 & $\begin{array}{l}\text { controller in complex } \\
\text { clauses }\end{array}$ & $\mathrm{Y}$ & $\mathrm{Y}$ & $\mathrm{Y}$ & $\mathrm{Y}$ & $\mathrm{N}$ & $\mathrm{N}$ \\
\hline & CORE INDICES: & $9 / 9$ & $9 / 9$ & $9 / 9$ & $7 / 9$ & $4 / 9$ & $1 / 9$ \\
1.00 & 1.00 & 1.00 & 0.77 & 0.44 & 0.11 \\
\hline
\end{tabular}

Table 6. Core indices of arguments in Puyuma

To facilitate the comparation, a summary of core indices of A and P in Balinese, Indonesian, and Puyuma is given in Table 7 (based on the information in Table 5. The abbreviations PCORE, M-CORE, and S-CORE mean Prototypical Core, Marginal core, and Semi Core, respectively, as defined in (14).

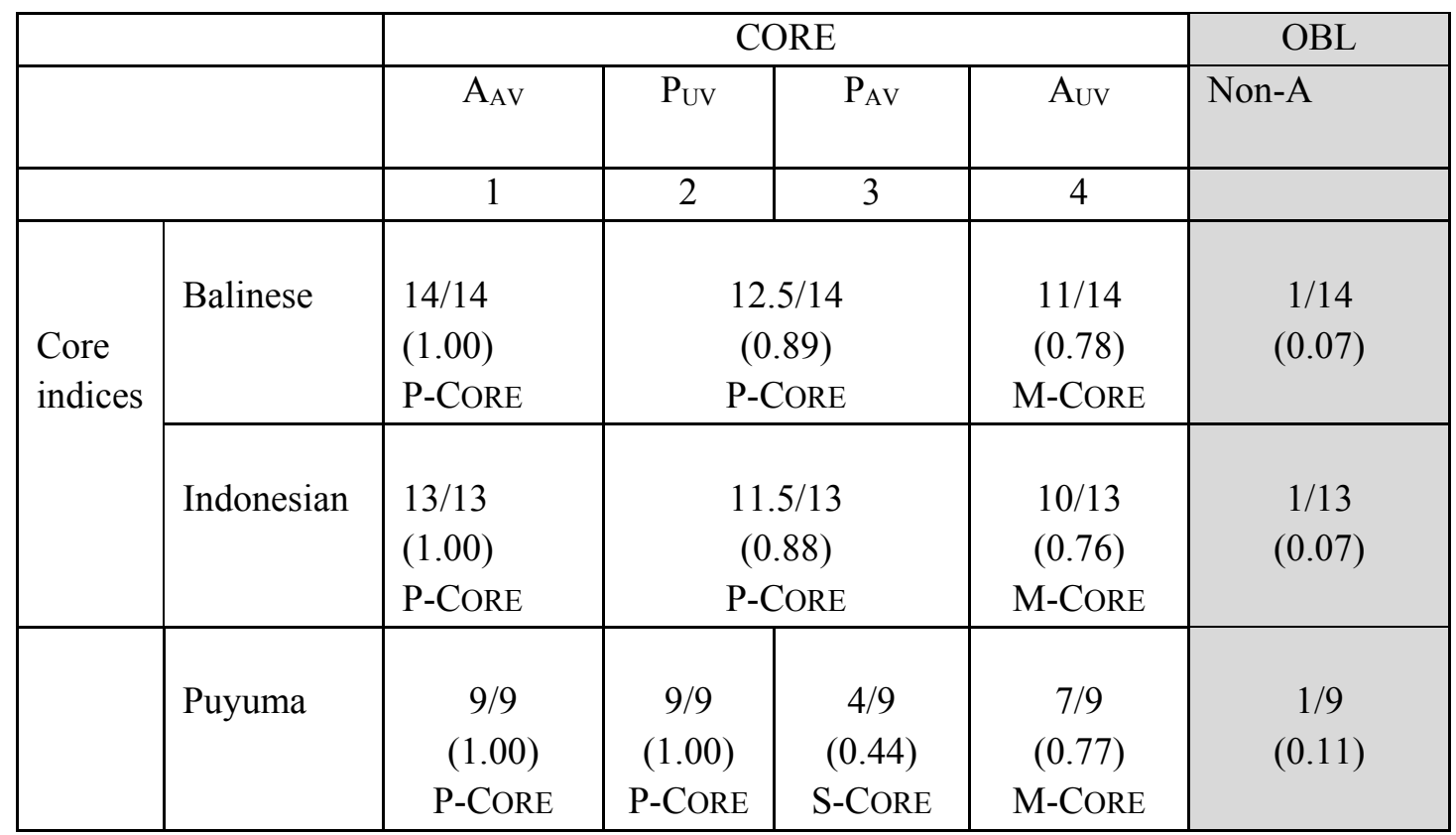

Table 7. Comparative core indices in Balinese, Indonesian and Puyuma

The first point is the similarity of the core indices of $\mathrm{A}$ in different voice types in the three languages. As seen from the table, $\mathrm{A}_{\mathrm{AV}}$ and $\mathrm{A}_{\mathrm{UV}}$ are two distinct core arguments, the top-most core (P-CORE; column 1) vs. a marginal core (M-CORE; column 4). In other words, the core index of $\mathrm{A}_{\mathrm{UV}}$ shows that it is not as strongly a core argument as $\mathrm{A}_{\mathrm{AV}}$ or $\mathrm{P}$ and that its core index does not qualify it as a prototypical core.

Nevertheless the core index evidence provides support for one aspect of symmetricality. That is, the UV alternation in these languages where the $\mathrm{A}$ is not selected as syntactic subject/pivot does not involve the demotion of A to Oblique (as is the passivisation case in an asymmetrical system like English).

The other side of the point is this. While it is true that AV-UV alternation is not the same as passivisation (for it does not demote the $\mathrm{A}$ into oblique status), it is also not wholly correct to 
claim that the switch from AV to UV alternation does not demote A. As evident from a close scrutiny of its coreness, the switch to UV results in a demotion of the core type of A. In our index-based classification in (14), it is one level down, from a prototypical core to a marginal core. The core status of $A_{U V}$ is lower than that of $\mathrm{P}$.

The second point to note from the table is the difference of the core status of $\mathrm{P}$ (columns 2 and 3). The core status of $\mathrm{P}$ in Balinese/Indonesian remains constant in the AV-UV alternation, providing good support for voice symmetricality. That is, the core status of $\mathrm{P}$ remains Prototypical Core in a voice switch to AV (or UV) (though as noted earlier the core status of A slightly changes in UV). The switch to AV in Indonesian/Balinese, therefore, is not in any way the same as antipassivisation, for the $\mathrm{P}_{\mathrm{AV}}$ is not classifiable as an Oblique in our scale. ${ }^{21}$

In contrast, $\mathrm{P}_{\mathrm{AV}}$ and $\mathrm{P}_{\mathrm{UV}}$ in Puyuma are of two quite different types. $\mathrm{P}_{\mathrm{AV}}$ (column 3 in Table 7) is Semi Core whereas $\mathrm{P}_{\mathrm{UV}}$ (column 2 in Table 7) is Prototypical Core. $\mathrm{P}_{\mathrm{AV}}$ is obliquelike in that it shares Oblique properties such as Oblique phrasal marking, not being realized as a bound pronoun on the verb, no cross-referencing, and not a controller of unexpressed subject in an embedded clause.

In short, as far as $\mathrm{P}$ in the UV-AV alternation is concerned, the Puyuma voice system is less symmetrical than the Balinese/Indonesian voice system. Unlike in Indonesian/Balinese where the core status of $\mathrm{P}$ remains constant in the UV-AV alternation, the core status of $\mathrm{P}$ in the equivalent alternation in Puyuma is significantly different. $\mathrm{P}$ in Puyuma is demoted to Semi Core, though not radically to oblique status.

To conclude, voice symmetricality is a matter of degree. Evaluative statements of relative symmetricality can be made in relation to a language-specific internal system and across voice systems in different languages. Relative voice symmetricality in Balinese grammar, for example, indicates that the system is not really as symmetrical as one might have thought. Thus, as noted earlier, while the AV/UV switch does not affect the core status of $\mathrm{P}$ in Balinese, it does slightly affect the core status of $A$. The quantitative evidence of core index shows that $A_{U V}$ is downgraded to marginal core status, though not classifiable as an oblique. In short, symmetricality is observed in that neither $\mathrm{A}$ nor $\mathrm{P}$ is demoted to oblique, but some asymmetricality is also observed in that $\mathrm{A}$, not $\mathrm{P}$, is slightly downgraded.

Our comparative study on Balinese, Indonesian, and Puyuma also allows us to make a statement of relative symmetricality across voice systems. It appears that Puyuma's system is less symmetrical than the Balinese/Indonesian systems. While the switch to UV in these three languages shows the same effect on the core status of A (i.e., $A_{U V}$ is Marginal Core), the switch to AV has a quite different effect on the status of $\mathrm{P}$ in Puyuma. $\mathrm{P}_{\mathrm{AV}}$ in Puyuma is significantly demoted to Semi Core (close to Oblique), whereas $\mathrm{P}_{(\mathrm{AV})}$ in Indonesian and Balinese is Prototypical Core. In other words, Balinese/Indonesian voice systems treat $\mathrm{P}$ symmetrically in UV-AV alternation, but the Puyuma system does not quite do so.

\section{Investigation into borderline cases}

The borderline cases between core and oblique are of special interest. Research into this area could shed light on the nature of arguments and the related (syntactic) argument structure of the verb or verb class involved. It could lead to a better understanding of variation in argument expressions within a language or across languages. In the following subsections, data from Indonesian and other Austronesian languages of Indonesia are discussed. 
4.1 The stimulus argument of the verbs 'like' and 'hate' in Indonesian and Balinese There is some evidence that Balinese grammar imposes a more categorical core-oblique distinction than Indonesian. Consider (16), which shows the difference in status of the stimulus argument (i.e., $\mathrm{NP}_{2}$ ) of the verb 'like', which is demen in Balinese and suka in Indonesian.
(a)
i) Balinese:
ii) Indonesian:
(b) $\mathrm{NP}_{1}$ demen $\mathrm{PP}$
$\mathrm{NP}_{1}$ suka $\mathrm{PP}$
$\mathrm{NP}_{1}$ suka $\mathrm{NP}_{2}$
iii) Status of the stimulus NP: (oblique) ?
(c) $\quad \mathrm{NP}_{1} N$-demen-in $\mathrm{NP}_{2}$
$\mathrm{NP}_{1}$ meN-suka-i $\mathrm{NP}_{2}$
(object)

As noted, both Balinese and Indonesian allow structures (16)a and (16)c: bare verbs followed by stimulus obliques (a) and transitive applicative verbs with stimulus NP objects (c). However, Indonesian further allows the structure shown in (16)b for which it is barred in Balinese. This is the structure containing a bare verb followed by a stimulus NP.

The question now is, what is the syntactic status of the stimulus NP in Indonesian structure (16)b? The core index of this stimulus NP was calculated and displayed in Table 8 for comparison with the other two structures. ${ }^{22}$

\begin{tabular}{|c|c|c|c|c|}
\hline & & 1 & 2 & 3 \\
\hline & & $\begin{array}{c}\text { STIMULUS OF } \\
{[\text { MEN-SUKA-I NP } 2]}\end{array}$ & $\begin{array}{c}\text { STIMULUS OF } \\
{\left[\text { SUKA NP }_{2}\right]}\end{array}$ & $\begin{array}{l}\text { STIMULUS OF } \\
\text { [SUKA PP] }\end{array}$ \\
\hline 1 & Subcategorized? & $\checkmark$ & $\checkmark$ & $\checkmark$ \\
\hline 2 & Obligatory & $\checkmark$ & $*$ & $*$ \\
\hline 3 & Categorical marking & NP & $\mathrm{NP}$ & $\overline{\mathrm{PP}}$ \\
\hline 4. & QF with semua 'all' & $\checkmark$ & $*$ & $*$ \\
\hline 5 & $\begin{array}{l}\text { Topicalisation of } \\
\text { possessor phrase }\end{array}$ & $\checkmark$ & $\checkmark$ & $*$ \\
\hline 6 & $\begin{array}{l}\text { Topicalisation of with a } \\
\text { resumptive pronoun }\end{array}$ & $\sqrt{ }$ & $\checkmark$ & $*$ \\
\hline 7 & Depictive predicate & $\checkmark$ & $\checkmark$ & $*$ \\
\hline 8 & $\begin{array}{l}\text { Elided (= zero) in } \\
\text { Imperative }\end{array}$ & $*$ & $*$ & $*$ \\
\hline 9 & Binding: binder of a core & $*$ & $*$ & * \\
\hline 10 . & $\begin{array}{l}\text { Participation in } \mathrm{AV} / \mathrm{UV} \\
\text { voice alternation }\end{array}$ & $\checkmark$ & $*$ & $*$ \\
\hline 11 & Proclitic on the verb & $\sqrt{ }$ & $*$ & $*$ \\
\hline 12 & $\begin{array}{l}\text { Structural positions: } \\
\text { (a) fixed and/or A- } \\
\text { position, } \\
\text { (b) not fixed and/or non-A } \\
\text { position }\end{array}$ & (a) & (a) & (b) \\
\hline & Core index: & $\begin{array}{l}10 / 12 \\
(0.83)\end{array}$ & $\begin{array}{c}6 / 12 \\
(0.50)\end{array}$ & $\begin{array}{c}1 / 12 \\
(0.08)\end{array}$ \\
\hline
\end{tabular}

Table 8. Core indices of the stimulus arguments in suka-based constructions. 
The table clearly shows that the stimulus argument in the three constructions has different degrees of coreness. The stimulus NP of the applicative [MEN-SUKA-I NP] structure (column 1) is a highly core argument (object) (with a core index of 0.83 ). In contrast, the stimulus PP of [SUKA PP] is an oblique (with a core index of 0.08 , column 3 ). The stimulus NP of [SUKA NP] (with a core index of 0.50 , column 2 ) is, according to the classification in (14), semi-core.

How does the notion of 'semi-core', adopted here, fit with syntactic transitivity? I suggest that it can also be used to define syntactic (semi-) transitivity. A structure having one core and one semi-core argument is 'semi-transitive'. A structure having two core arguments and one semi-core is 'semi-ditransitive'. The three structures with the root suka in Indonesian can be analysed as having different degrees of syntactic transitivity, as shown in (17). The question remains as to what kind of grammatical relation the semi-core stimulus argument holds in surface syntax. It is called 'semi object' ${ }^{23}$ in (17) b, in contrast to a core argument in the applicative structure (17)c. The stimulus argument in the applicative structure (i.e., $\mathrm{NP}_{2}$ in (17)c) is widely accepted as an object in the AV structure. I return to the issue of surface grammatical relations in section 5 .

\begin{tabular}{|l|l|l|l|l|}
\hline$(17)$ & & $\begin{array}{l}\text { STRUCTURES/ } \\
\text { CONSTRUCTIONS }\end{array}$ & $\begin{array}{l}\text { SYNTACTIC } \\
\text { TRANSITIVITY }\end{array}$ & $\begin{array}{l}\text { STATUS OF STIMULUS } \\
\text { ARGUMENT }\end{array}$ \\
\hline & a. & {$\left[\mathrm{NP}_{1}\right.$ suka $\left.\mathrm{PP}\right]$} & Intransitive & non-core or oblique \\
\hline & b. & {$\left[\mathrm{NP}_{1}\right.$ suka $\left.\mathrm{NP}_{2}\right]$} & Semi transitive & semi-core, or semi-object \\
\hline & c. & {$\left[\mathrm{NP}_{1}\right.$ meN-suka-i $\left.\mathrm{NP}_{2}\right]$} & Transitive & core, or object \\
\hline
\end{tabular}

Note that the term 'semi-transitive' is used here in relation to syntactic transitivity on the basis of the degree of coreness of an argument it is associated with. The term semitransitive (or ambitransitive) is also generally used to refer to a verb that can appear in both intransitive and transitive frames, typically with the object being optionally present or being optionally adpositionally marked. While these could be signs of semi-coreness, it is not always the case that they signal syntactic semi-transitivity. In fact, there may be no semi-transitive structure involved, as in the following case with the Indonesian verb benci 'hate'.

Like suka 'like', the Indonesian verb benci 'hate' can appear in the structures $\left[\mathrm{NP}_{1}\right.$ benci $\mathrm{PP}]$ and $\left[\mathrm{NP}_{1}\right.$ benci $\left.\mathrm{NP}_{2}\right]$, equivalent to $\left[\mathrm{NP}_{1}\right.$ suka $\left.\mathrm{PP}\right](17) \mathrm{a}$ and $\left[\mathrm{NP}_{1}\right.$ suka $\left.\mathrm{NP}_{2}\right](17) \mathrm{b}$, respectively, with $\mathrm{PP} / \mathrm{NP}_{2}$ being the stimulus argument. This gives the impression that the stimulus argument is optionally prepositionally marked for both verbs and that we have cases of semi-transitive structures for both verbs. However, the degree of coreness of the stimulus NP of benci and suka differs, as shown in Table 9. The stimulus NP of benci (column 1) is a core (though not a prototypical core, with a core index of 0.66). In contrast, the stimulus NP of suka (column 2) is semi-core (with a core index of 0.50).

To conclude, the evidence shown by benci and suka highlights the point that coreness is not semantically predictable: a stimulus of semantically similar verbs does not necessarily have the same core status (core, semi-core or oblique).

\begin{tabular}{|c|c|c|c|}
\hline & 1 & 2 & 3 \\
\hline & STIMULUS OF & STIMULUS OF \\
{$[$ BENCI + NP $]$} & STIMULUS OF \\
& & $\begin{array}{c}\text { SUECI/SUKA } \\
+ \text { PP }]\end{array}$ \\
\hline
\end{tabular}




\begin{tabular}{|c|c|c|c|c|}
\hline 1 & Subcategorized for & $\overline{\text { yes }}$ & yes & yes \\
\hline 2 & Obligatory & $*$ & $*$ & * \\
\hline 3 & Categorical marking & NP & NP & $\mathrm{PP}$ \\
\hline 4 & QF with semua 'all' & $*$ & * & * \\
\hline 5 & $\begin{array}{l}\text { Topicalisation of possessor } \\
\text { phrase }\end{array}$ & $\checkmark$ & $\checkmark$ & * \\
\hline 6 & $\begin{array}{l}\text { Topicalisation of with a } \\
\text { resumptive pronoun }\end{array}$ & $\checkmark$ & $\sqrt{ }$ & * \\
\hline 7 & Depictive predicate & $\checkmark$ & $\checkmark$ & * \\
\hline 8 & Elided (= zero) in Imperative & $\sqrt{ }$ & * & * \\
\hline 9 & Binding: binder of a core & * & $*$ & * \\
\hline 10 & $\begin{array}{l}\text { Participation in UV } \\
\text { alternation }\end{array}$ & $\checkmark$ & $*$ & $*$ \\
\hline 11 & Proclitic on the verb & * & $*$ & * \\
\hline 12 & $\begin{array}{l}\text { Structural positions: } \\
\text { (a) fixed and/or A-position, } \\
\text { (b) not fixed and/or non-A } \\
\text { position }\end{array}$ & (a) & (a) & (b) \\
\hline & Core index: & $\begin{array}{c}8 / 12 \\
(0.66)\end{array}$ & $\begin{array}{c}6 / 12 \\
(0.50)\end{array}$ & $\begin{array}{l}1 / 12 \\
(0.08)\end{array}$ \\
\hline
\end{tabular}

Table 9. Core indices of the stimulus of benci and suka compared.

\subsection{The A argument of the di-verb in Indonesian}

The di-verb in Indonesian has been traditionally considered a passive verb (Chung, 1976; Cole, Hermon, \& Yanti, 2008, among others; Sneddon, 1996; Vamarasi, 1999). However, Arka and Manning (2008) has demonstrated that $d i$ - is not truly a passive prefix (in all cases). Rather, it is an Undergoer-oriented prefix, selecting the core Undergoer (i.e., P or G) as grammatical SUBJ (hence like a passive) but leaving the status of the underlying A unspecified. The status of A as an oblique or not depends on the larger construction where the di-verb is. It has been demonstrated in Arka and Manning (2008) that the actor argument of di-verb is an oblique when it is realized as a PP and is a core when it is a pronominal enclitic on the verb. The degrees of A's coreness in di-verbs has not been investigated before. In what follows, I revisit the different expressions of $\mathrm{A}$ in di-verbs and examine their core indices. Apart from providing further support for degrees of coreness in Indonesian, evidence from core index shows that diconstructions do not belong to a single homogenous type and that they cannot all be classified as passives.

The di-verb allows three different expressions of the actor argument: a pronominal clitic on the verb (DI-VERB=PRO), an independent NP (DI-VERB NP), and a PP (DI-VERB PP). Each of these is exemplified in (18).
(18) a. Saya di-lihat=nya/mereka
$1 \mathrm{~s} \quad \mathrm{di}-\mathrm{see}=3 \mathrm{~s} / 3 \mathrm{p}$
'Me, (s)he/they saw' (or I was seen by her/him/them)
$(\mathrm{DI}-\mathrm{VERB}=\mathrm{PRO})$ 

b. Saya di-lihat orang itu (DI-VerB NP)
1s di-see person that
'I was seen by the person'
c. Saya di-lihat oleh orang itu
1s di-see by person that
'I was seen by the person / by people'

\section{(DI-VERB PP)}

The degrees of the coreness of the three different expressions of the A argument are calculated and the core indices are displayed in Table 10. There are three points to note.

First, the PP A in the [DI-VERB PP] construction certainly is an oblique A, having a core index of 0.00 (column 3).

Second, the NP A of the [DI-VERB NP] construction has a low core index (0.29) (column 2 ), which according to our classification in (14) is marginally oblique. Put differently, it shows a considerable degree of obliqueness, even though its obliqueness is not as prototypical as that of the PP A of the [DI-VERB PP] construction. The finding here provides support for Arka and Manning (2008) who classify the NP A of the [DI-VERB NP] as an oblique on the basis of reflexive binding alone.

\begin{tabular}{|c|c|c|c|c|}
\hline & & 1 & 2 & 3 \\
\hline & & $\begin{array}{c}\text { A OF } \\
\text { DI-VERB }=\text { PRO }\end{array}$ & $\begin{array}{c}\text { A OF } \\
\text { DI-VERB NP }\end{array}$ & $\begin{array}{c}\text { A OF } \\
\text { DI-VERB PP }\end{array}$ \\
\hline 1 & Subcategorized for & * & $*$ & * \\
\hline 2 & Obligatory & No & No & No \\
\hline 3 & Categorical marking & not $P P$ & not PP & PP \\
\hline 4 & QF with semua 'all' & $*$ & $*$ & $*$ \\
\hline 5 & $\begin{array}{l}\text { Topicalisation of possessor } \\
\text { phrase }\end{array}$ & N/A & $*$ & $*$ \\
\hline 6 & $\begin{array}{l}\text { Topicalisation with a } \\
\text { resumptive pronoun }\end{array}$ & $\checkmark$ & $\checkmark$ & $?^{* *}$ \\
\hline 7 & Depictive predicate & $*$ & * & $*$ \\
\hline 8 & Elided (= zero) in Imperative & $\bar{\checkmark}$ & $\begin{array}{l}\checkmark \text { (only with } \\
\text { vocative NP) }\end{array}$ & $*$ \\
\hline 9 & Binding: binder of a core & $\bar{\checkmark}$ & * & * \\
\hline 10 & Voice marking on the verb & $d i$ & di- & di- \\
\hline 11 & Proclitic on the verb & $\checkmark$ & No & No \\
\hline 12 . & $\begin{array}{l}\text { Structural positions: } \\
\text { (a) fixed, A-position, } \\
\text { (b) not fixed, non-A position }\end{array}$ & (a) & (a) & (b) \\
\hline & Core index & $\begin{array}{c}6 / 12 \\
(0.50)\end{array}$ & $\begin{array}{l}3.5 / 12 \\
(0.29)\end{array}$ & $\begin{array}{c}0 / 12 \\
(0.00)\end{array}$ \\
\hline
\end{tabular}

Table 10. Core indices of the A arguments of $d i$-constructions

Third, the core index of the pronominal A argument of the [DI-VERB=PRO] construction shows that it is a semi-core argument. It has the same core index as the stimulus NP of suka shown in 
Table 8 , which is 0.50 . A summary of the core status and related syntactic transitivity of the diconstructions is given in (19).

\begin{tabular}{|l|l|l|l|l|}
\hline$(19)$ & & $\begin{array}{l}\text { CONSTRUCTIONS } \\
\text { WITH } d i-\end{array}$ & $\begin{array}{l}\text { CORE STATUS OF THE ACTOR } \\
\text { (CORE INDEX) }\end{array}$ & $\begin{array}{l}\text { SYNTACTIC } \\
\text { TRANSITIVITY }\end{array}$ \\
\hline & a. & DI-VERB=PRO & semi-core $(0.50)$ & semi-transitive \\
\hline & b. & DI-VERB NP & not a typical oblique $(0.29)$ & intransitive \\
\hline & c. & DI-VERB PP & a typical oblique $(0.00)$ & intransitive \\
\hline
\end{tabular}

Note that different di-verb constructions are associated with different degrees of syntactic transitivity. Therefore, it is not absolutely accurate to claim that all $d i$-verbs are passives, or that $d i-$ is a passive marker. In particular the [DI-VERB=PRO] construction is syntactically not intransitive, but 'transitive-like', even though it is not really transitive in the sense of having two highly core arguments. Indeed, the [DI-VERB=PRO] construction does not conform to the information structure typical of a passive: its patient subject is often new or indefinite, the (PRO) (non-subject) agent maintains topic continuity in the discourse (at least in narrative texts), and the construction should be translated into 'active' in English (McCune, 1979; Purwo, 1989).

Furthermore, the realisation of the A argument as a semi-core argument, as in DI-VERB=PRO, raises problems for the analysis of surface grammatical relations (discussed further in section 5).

\subsection{Semi-core in other Austronesian languages of Indonesia}

There has not been much discussion on degree of coreness, especially as regards the borderline cases between core and obliques, especially in the literature on the Austronesian languages of Indonesia. This is perhaps partly because the languages described thus far may indeed lack systematic behavioural properties related to core-oblique distinctions in their grammars. It might also be due to the common practice of focusing first on the clear cases, and leaving the borderline cases for later studies. A precise analysis of such borderline cases commonly requires a deep understanding of the grammar of the language, which almost always calls for lengthy research.

Fortunately, however, there has been a growing body of literature presenting quite detailed studies on the grammatical relations of the Austronesian languages of Indonesia. In what follows, I note cases that could be taken as reflecting semi-coreness. (The discussion may be biased, since it is based on the limited data with which I am familiar.)

\subsubsection{Oblique object in Tukang Besi?}

Tukang Besi (Donohue, 1999, 2002; 1998) shows evidence of grammatical subject/pivot (PIV), core and voice alternations. Core arguments in this language have the following four properties: i) They are obligatory (but the subject is not always so); ii) They are realized as verbal bound forms on the verb, cross-referenced by a te-marked NP for non-PIV and by na for PIV; iii) An object core can alternate with a subject in an undergoer voice and in passive; iv) A core argument can be the head of a relative clause. Obliques are negative with respect to all these properties. Quantifier float is a property of subject/pivot in Tukang Besi, not a property of core as in Balinese and Indonesian (see 3.1). 
A case of an argument with intermediate status is reported for the verb 'thirsty' in Tukang Besi (20)a. ${ }^{24}$ While coded by the core marker te-, the stimulus argument of 'thirsty' otherwise shows oblique properties. It is optional (indicated by the parentheses in (20)a), cannot alternate with the subject/pivot marked by $n a(20) \mathrm{b}$, and cannot be the head of a relative clause (20)c. Donohue calls it a 'false object' or 'oblique object', and classifies it as a kind of oblique because the stimulus argument of other verbs of the same type is expressed as an oblique in this language. Note that even if two verbs belong to the same verb class, this does not guarantee that a given role will have the same core status for both verbs, as evidenced by the stimulus argument of benci and suka in Indonesian, section 4.1 above.

However, given the fact in Tukang Besi that the stimulus argument satisfies one out of four core properties (i.e., a core index of 0.25 ), it is certainly classifiable as an oblique. In our scale shown in (14), it is marginally oblique, not a prototypical one. ${ }^{25}$

$$
\begin{aligned}
& \text { (20) a. Ku-motinodo'u (te tee) (Tukang Besi) } \\
& 1 \text { sg-thirsty CORE tea } \\
& \text { 'I'm thirsting after some tea' } \\
& \text { b.* ku-muntondo'u-ke na tee } \\
& 1 \text { sg-thirsty-3OBJ NOM tea } \\
& \text { c. *Te ana te tee i-omtindo'u-no } \\
& \text { CORE this CORE tea OP-thirsty-3POSS } \\
& \text { 'This is the tea that is thirsted after.' }
\end{aligned}
$$

(Donohue, 1998:90-91)

\subsubsection{Obliquely marked applied arguments}

There have also been cases of 'obliquely or adpositionally marked cores' reported in other Austronesian languages of central and eastern Indonesia. Of particular interest are two alternative three-place applicative structures shown in (21), encountered in languages such as Pendau, Bima, and Taba.

(21) a. Applicative structure 1: [A:NP Verb-appl. Gappl:NP $\left.\quad \mathrm{T}_{: \mathrm{NP}}\right]$

b. Applicative structure 2 [A:NP Verb-appl T:NP $\left.\mathrm{G}_{\text {appl:PP }}\right]$

Both structures have the head verb with same applicative morphology. The difference is on the expression of the $\mathrm{G}$ argument as well as its relative order with $\mathrm{T}$ and the verb. In Applicative 1 (21)a, all three arguments (A, G, T) appear as bare NPs; i.e., G is not adpositionally marked. The applied argument $\left(\mathrm{G}_{\mathrm{APPL}}\right)$ comes immediately after the verb. In Applicative 2 (21)b the

\begin{tabular}{|c|c|c|c|c|}
\hline (22) a. & $\begin{array}{l}A^{\prime} u \\
\text { 1SG/AB }\end{array}$ & $\begin{array}{l}\text { mombagia' } \\
\text { M-pong-bagi-a' } \\
\text { IR-SF/PT-give-T }\end{array}$ & $\frac{o O}{2 \mathrm{SG} / \mathrm{AB}}$ & $\begin{array}{l}\text { bulaan } \\
\text { gold }\end{array}$ \\
\hline
\end{tabular}
$\mathrm{G}_{\mathrm{APPL}}$ argument is adpositionally marked. In addition, the applied argument does not come immediately after the verb. Thus, $\mathrm{G}_{\mathrm{APPL}}$ is registered as 'core' on the verb by the applicative morphology but is marked as an oblique by the adposition. In a way, the alternation in (21) is just like the dative-shift in English, except that the verb in these languages is morphologically complex with an overt applicative/transitivizer affix.

In what follows, the pattern in Pendau is discussed first, followed by the pattern in Bima and Taba. Consider the Pendau data in (22) (Quick, 2007): 


\section{b. Ula uo nombagia' doi' sono langkai uo snake yonder N-pong-bagi-a' money COM male yonder RE-SF/PT-give-TZ}

'That snake gave the money to that man.' (Quick 2007:291)

Sentence (22)a illustrates Applicative 1 and (22)b illustrates Applicative 2. Both verbs in (22) contain an overt transitivizer suffix $-a$ '. They differ in the mood involved (IR(realis) vs $\mathrm{RE}$ (ealis)). Quick is unsure about the precise syntactic status of the sono NP in (22)b, whether it is a kind of object that is obliquely marked for its 'goal' semantic role, or whether it is indeed an oblique. ${ }^{26}$

While Quick (2007) does not explicitly list diagnostic properties of coreness in Pendau, it is clear from his description that there are at least six core properties in this language: i) structural positions close to the head predicate with $\mathrm{T}$ or oblique (i.e., second object) following a typical core $(\mathrm{A} / \mathrm{P} / \mathrm{G})$, ii) category marking of NP (core) (in contrast to PP (non-core)), iii) appearing in Absolute/Genitive core case, iv) participation in UV(or Inverse) alternation, v) registered on the verb by voice/applicative morphology, vi) subcategorized for, and vii) obligatory.

Given these properties, the $\mathrm{G}$ argument (sono langkai uo) in (22)b appears to satisfy the last three core properties; hence a core index of 0.42 . This makes it a low-end semi core argument in our classification. The $\mathrm{G}$ argument in (22)a is clearly a prototypical core satisfying all core properties (an index of 1.00). The Pendau alternation shown in (22) may look like a dative shift as in English 'give'. It is slightly different, however, because the corresponding PP $\mathrm{G}$ argument in Pendau (22)b is a semi-core argument, rather than a prototypical oblique PP argument as in English.

The examples shown in (23) are from Bima (Jauhary, 2000). Sentence (23)a involves an applicative ditransitive verb (Applicative 1) with the beneficiary (G) nahu appearing immediately after the verb. Sentence (23)b is Applicative structure 2, with the verb having applicative morphology but the supposedly applied $G$ argument obligatorily marked by a preposition (ruu nahu). Applicative 2 in (23)b is triggered by the passivisation of the $\mathrm{T}$ of the applicative verb, in which case $T$ must be prototypical core and $G$ cannot be so; hence, the contrast between (23)b and (23)c-d. Note that G in (23)c-d cannot appear as a bare NP-the coding property of core in Bima.

$$
\begin{aligned}
& \text { (23) a. Sia ndawi-wea-na } \underline{\boldsymbol{n a h u}} \text { kuru nasi (Bima) } \\
& \text { 3SG make-APPL-3.REAL } \overline{1 \mathrm{SG}} \text { cage bird (AV) } \\
& \text { '(S)he has made a bird cage for me' (Appl. 1) } \\
& \text { b. Kuru nasi ede ndawi-wea ba sia } \underline{\text { ru'u nahu }} \text { (PASS) } \\
& \text { cage bird that make-APPL by } 3 \mathrm{SG} \text { for } 1 \mathrm{SG} \text { (Appl.2) } \\
& \text { 'The bird cage was made by him/her for me' } \\
& \begin{array}{l}
\text { c.* Kuru nasi ede ndawi-wea } \frac{\text { nahu }}{\text { ba sia }} \\
\text { cage bird that make-APPL } 1 \mathrm{SG} \text { by } 3 \mathrm{SG} \\
\text { 'The bird cage was made by him/her for me' }
\end{array} \\
& \text { d. * uru nasi ede ndawi-wea ba sia nahu (cf. b above) }
\end{aligned}
$$


Previous studies on Bima (Arka, 2008; Jauhary, 2000; Wouk, 2002) show that core properties in Bima include at least the following properties: i) bound pronominal or cross-reference on the verb, ii) NP rather than PP, iii) structural positions close to the head verb (i.e., A-Verb-P, AVerb-G-T), iv) selectable as grammatical subject (i.e., participate in passive alternation), v) registered on the verb, vi) subcategorized for, and vi) obligatory.

The core index of the $\mathrm{G}$ argument in Bima can now be assessed. The immediately postverbal G nahu of Applicative 1 (23)a is clearly a prototypical core argument as it has a core index of 0.85 (i.e., satisfying six out of seven core properties in Bima). The $\mathrm{G}$ argument can, for example, be selected as subject in the passive construction, as seen in (24).

$\begin{array}{llll}\text { (24) Nahu ndawi-wea ba sia kuru nasi } & \text { (Bima) } \\ 1 \mathrm{SG} \text { make-APPL by 3SG cage bird } & \text { (PASS) } \\ \text { 'For me, the bird cage was made by him/her' } & \end{array}$

The $\mathrm{G}$ argument of Applicative 2 in Bima (23)b shows a core index of 0.42, satisfying the last three core properties listed above. This makes it a semi-core argument rather than a prototypical oblique. It is core-like because it is registered on the verb by the applicative morphology; applicative morphology generally 'promotes' a non-core argument to core status in Bima, as indeed is the case with Applicative 1 (23)a. Moreover, the applied argument in Applicative 2 is also subcategorized for and obligatory: the sentence without it would be unacceptable. It should be noted that the G argument of Applicative 2 does not participate in the passivisation: (24) is the passive counterpart of Applicative 1 (23)a, not that of Applicative 2 (23)b. Passivisation of Applicative 2 would give a structure like (24) whose preposition ru'u is stranded, which is unacceptable in Bima.

In short, the obliquely marked applied argument $(\mathrm{G})$ in Bima is a semi-core argument. Its core index shows that it is of the same category as its corresponding $G$ in Applicative 2 in Pendau. We now turn to a similar case in Taba.

Unlike Pendau and Bima, Taba (Bowden, 2001) has no language-internal evidence for subjecthood and no voice system. (It does, however, show a very limited lexical 'passive'.) Crucially, it exhibits applicativisation of both syntactic types captured by the patterns shown in (21).

Bowden discusses a distinction between actor (A) and undergoer (U) arguments (i.e., cores) and adjuncts, but does not mention explicitly the distinction between core arguments and obliques. (Presumably, obliques and adjuncts are not clearly distinguished in Taba.) Taba is a split-S language with prototypical core arguments having the following properties: i) crossreferenced on the verb for A, ii) appearing as NPs, iii) structurally typically close/immediate to the head predicate, iv) registered on the verb (e.g., by applicative/causative morphology), v) made 'subject' in lexical passive, vi) subcategorized for, and vii) obligatory. Given these properties, we can now address the issues in Taba.

In fact, what Bowden calls a 'remote' $U$ in Taba belongs to Applicative 2 and exemplifies an argument with an intermediate degree of coreness, called semi-core in this paper. The evidence comes from its core index of 0.50 (i.e., 3.5 out of 7 properties): appearing as an NP/PP (counted as 0.5), registered on the verb by the applicative morphology, subcategorized for and obligatory. Each property is further discussed below.

First, the remote undergoer, the instrument peda, in (25) is optionally marked by the preposition ada. This is not a property of either 'primary' or 'close' undergoers in Taba: the 
'primary' undergoer (yak) and the 'close' undergoer (yan), as in example (26), must both be bare NPs. Note that (25) and (26) are applicative sentences representing Applicative 2 and Applicative 1, respectively. ${ }^{27}$

(25) Ahr

$\begin{aligned} & \text { Ahmad npunak kolay } \quad \text { (ada) peda } \\ & \text { name n=pun=ak snake with machete }\end{aligned}$
3s-kill-APPL
'Ahmad killed the snake with a machete'

(Bowden 2001:204)

(26) Banda notik yak yan

name $\quad \mathrm{n}=\mathrm{ot}-\mathrm{ik} \quad 1 \mathrm{sg} \quad$ fish

$3 \mathrm{~s}=$ get-APPL

'Banda gave me some fish'

(Bowden 2001:209)

It should be noted that a true non-core, e.g., the instrument in the non-applicative structure is obligatorily marked by a preposition, as seen in (27). In short, optional marking of PP (or NP) can be taken as indicating an intermediate status of core/oblique; hence a score of 0.5 is given in the core index calculation.

(27) $A$ hin

$\begin{array}{lllll}\text { Ahmad } & \text { npun } & \text { kolay } & \text { (ada peda) } \\ \text { name } & \mathrm{n}=\text { pun } & \text { snake } & \text { with machete }\end{array}$

'Ahmad killed the snake with a machete'

(Taba)

(Bowden 2001:204)

Secondly, in terms of subcategorisation, a 'remote' applied argument, such as (ada) peda in (25), is part of the inherent meaning of the applicative verb, and is obligatorily present. (However, it may be ellipsed and, if so, it is understood to be implicitly present in a given context.) A non-core instrument of the type in (27) is not part of the meaning of the verb and is therefore not obligatory.

Thirdly, in terms of its structural position, the remote undergoer is positioned after the primary undergoer $(\mathrm{P})$ and cannot possibly alternate with the primary undergoer.

Fourthly, a remote undergoer can never be made the 'subject' of the 'passive' ta-verb (Bowden p.c.). The following structure illustrates a passive structure with the verb marked by ta- where it is the primary undergoer kofi 'coffee' which appears preverbally, and the applied locative, meja 'table', remains sentence-finally.
(28) kofi tasoak
coffee ta-so-ak
meja li (appl. verb)
table LOC
DETR-exit-APPL
'Coffee is split all over the table.' (ex. 113, p.220)

To conclude, the evidence from core index allows us to claim with confidence that the remote undergoer in Taba is a semi-core argument, an argument whose degree of coreness is less than its primary $(\mathrm{P})$ counterpart. On our analysis, it is equivalent to the semi-core arguments so far discussed in Indonesian, Pendau, and Bima.

Finally, there is a note on the alternation that involves a semi-core argument. In some languages, Applicative 1 may alternate with Applicative 2, as in Pendau and Bima. In other languages, as in Taba, the alternation is not possible. This is perhaps due to language-specific differentiation of applicative functions. In Taba, for example, Applicative 1 is associated with the goal/benefactive role while Applicative 2 is associated with instrumental and locative roles. 
While both Applicatives 1 and 2 are possible, one might be preferred over the other. Alune (Florey, 2001), an Austronesian language of Maluku, also shows Applicatives 1 and 2, but is reported to prefer Applicative 2, even for the beneficiary role. Sentence (29) below is an example of Applicative 2 in Alune showing a verb with an overt applicative affix and the beneficiary expressed as a PP.

$\begin{array}{llll}\mathrm{Au} \text { dilu-'e atu mama 'ai } & \text { bapa=si } \\ 1 \mathrm{~s} \text { give-APP BEN mother(AM) and } & \text { father(AM)=3P } \\ \text { 'I gave (it) to mother and father and them.' }\end{array}$

(Alune)

\subsubsection{The isolating languages of Flores}

The Austronesian languages of Flores, such as Manggarai (Arka \& Kosmas, 2005; Kosmas, 2000; Verheijen, 1977), Rongga (Arka, 2005), Keo (Baird, 2002), Sikka (Sedeng, 2000), and Lio (Sawardi, 2000) are isolating. They do not have voice and applicative morphology on the verb. Nevertheless, they do exhibit grammatical alternations comparable to morphological voice and applicative phenomena in the non-Flores languages discussed so far. The absence of applicative morphology turns out to blur the core-oblique distinction.

The description of Palu'e (Donohue 2005) shows that core arguments in this language show the following properties: i) structurally in core argument position (i.e., in canonical AVerb-P, A is in subject position and $\mathrm{P}$ in object position), ii) allowing simple quantifier float, iii) ability to bind a core reflexive argument, iv) typically NPs, v) participate in analytic (activepassive) voice alternation, vi) subcategorized for, and vii) obligatory.

Now, consider the Palu'e data in (30) below, where the stimulus argument of the verb 'love' must be prepositionally marked. This prepositionally marked NP is a rather exceptionally case-marked argument of the verb. Donohue argues that it is a propositionally marked P (i.e., object) rather than an oblique in Palu'e. Applying our core index analysis, it is actually a (higher-end) semi-core argument. Its core index is 0.57 (i.e., satisfying four out of seven core properties). Its properties can be noted as follows. The PP stimulus immediately follows the verb, like $\mathrm{P}$, presumably in the complement position within the verb phrase. In terms of categorical expression, it cannot be a typical P, because it cannot appear as a bare NP, as evidenced by the unacceptability of (30)b. The stimulus argument, however, can alternate with the subject in the 'analytic passive' as shown in (31). Donohue (2005) argues that (31)a is a passive-like structure with the 'fronted' $P$ having subject properties in the language. (Note that this alternation would require both passive and applicative marking on the verb in a language like Balinese.) The stimulus argument is certainly not an adjunct since it is an inherent part of the meaning or argument structure of the verb (i.e., subcategorized for) and is obligatorily present. Nor is it a 'real' oblique, since it shows a property of being core, a possible passive subject (31)a. (However, I conclude below that passivisation is not always a good test of objecthood.)

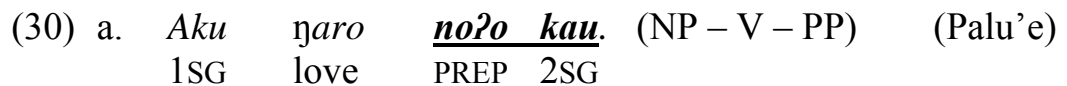

$$
\begin{aligned}
& \text { 'I love you.' } \\
& \text { b. * Aku yaro kau }
\end{aligned}
$$


(31) a. $\frac{\boldsymbol{I a} \text { aku yaro. }}{\text { 3SG } 1 \mathrm{SG} \text { love }}$
'I love him.'

b. ${ }^{*}$ No?o ia aku yaro.

The crucial empirical point to note from the Palu'e data is that (analytic) passive voice alternation may involve the promotion of not only typical object (i.e., P) but also a semi-core to grammatical subject.

In fact, other languages of central and western Flores, such as Manggarai and Rongga, also show a similar case. They even show cases where an oblique or adjunct-like argument can be directly promoted to the (passive) subject. That is, there is no alternative (active voice) structure for the same verb in which case the non-core argument is promoted to $\mathrm{P}$ (or object). In what follows, I discuss the data from Manggarai first, followed by the data from Rongga.

The clause in Manggarai is canonically A-V-P; core arguments (A, P, G, T) are bare NPs, whereas Obliques and adjuncts are PPs (Arka \& Kosmas, 2005; Kosmas, 2000). The only ditransitive structure allowed in Manggarai is for the verb teing 'give' (Kosmas, 2000: 61). Hence, the verb pande 'make' (32)a has no active ditransitive structure where the G (beneficiary) argument appears as the first object. Sentence (32)b is unacceptable; this A-VerbG-T structure would be fine for the verb 'give'. (The roles within angle brackets $<>$ in (32) are core arguments.)
(32) a. Hia pande layang-layang (te hi Ali) 3SG make kite-kite for Art name $<\mathrm{A}, \mathrm{P}>\mathrm{G}$ '(S)he made kites for Ali'
(Manggarai)
(monotrans.)

\section{b.*Hia pande hi Ali layang-layang \\ 3SG make Art name kite-kite $\quad *<\mathrm{A}, \mathrm{G}, \mathrm{T}>$}
'(S)he made kites for Ali' (*ditransitive)

Manggarai, like Palu'e, has an analytic passive. Unlike Palu'e, the A argument in Manggarai is demoted into oblique and must be prepositionally marked. The following is the passive counterpart of (32)a, where the A argument hia is marked by le.
(33) Layang-layang kite-kite
pande le hia
'The kites were made by him/her for Ali'
for Art name (pass.)
(Manggarai) $<\mathrm{P}>\mathrm{A}, \mathrm{G}$

Crucially, however, the non-subcategorized and prepositionally marked unit te hi Ali 'for Ali' (32)a can also alternate with a passive subject. Sentence (34) below is another possible passive counterpart of (32)a, where hi Ali (G) is made core subject. Note that the $\mathrm{T}$ (theme/patient) layang-layang is still a core argument, coming postverbally:
(34) Hi Ali
pande
layang-layang le
$\underline{\text { le }}$ hia (Manggarai)
Art name make kite-kite by $3 \mathrm{SG}<\mathrm{G}, \mathrm{T}>\mathrm{A}$
'For Ali, the kites were made by him/her' (pass.)

Passivisation exemplified by (34) illustrates a direct promotion of a non-core to subject: its promotion to object in the active structure is not allowed in this language (cf. the unacceptability of (32)b). It is, in fact, also not possible for the G argument hi Ali to be an object in the passive structure (cf. sentence (33)): ${ }^{28}$ 


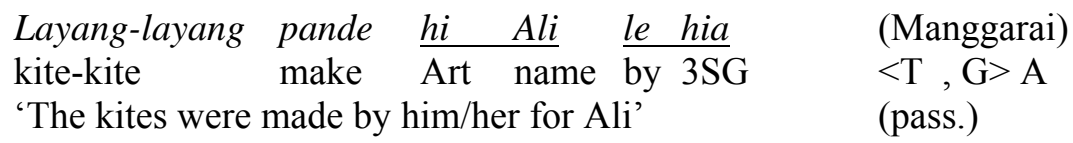

Rongga, like Manggarai, also exhibits analytic passive alternation where the agent appears as a PP. As in Manggarai, core arguments (A, P, G, and T) in Rongga are always NPs, whereas Obliques are PPs. The examples below from Rongga show that the locative oblique 'chair', (36)a, is directly promoted to subject in analytic passive, (36)c. The locative argument is never promoted to object, (36)b. The same pattern is seen in (37), where the locative argument 'bottle' of the three-place predicate lora 'pour, fill in' can never be object (37)b; hence the unacceptability of (37)b. However, the locative object can be directly promoted to subject (37)c.
(36) a. Selus po'o one kadhera ndau.
Selus sit on chair ndau
'Selus sat on the chair.'
b. * Selus po’o kadhera ndau. (loc object not possible)
c. Kadhera ndau po'o ne Selus chair ndau sit by Selus
'The chair was sat on by Selus.'
(37) a. Selus lora wae pai one peli (Rongga)
Selus pour water to in bottle
'Selus filled in/poured water into the bottle.'
b. * Selus lora peli ndau wae (loc object not possible)
Selus pour bottle that water
'Selus filled in/poured water into the bottle.'
(Rongga)
c. Peli ndau lora wae ne Selus
bottle that pour water by Selus
'The bottle was poured in (with) water by Selus.'

The lesson learned from the pattern in these Flores languages is that passivisation is not exclusively a diagnostic test for objecthood or for core-oblique/adjunct distinction. Promotion to passive subject is not necessarily from a (highly core) object. Semi-core and Oblique-like arguments can also directly alternate with a passive subject. Recall that these Flores languages lack applicative morphology. In languages that have it (e.g., Balinese), the applicative morphology can generally be used as diagnostic evidence for change of core-oblique status. However, even in the languages that have it (e.g., Taba and Bima, as discussed earlier), there is evidence from core index tests that application does not necessarily promote an argument to core status.

\subsection{Summary}

This paper has discussed syntactic core-oblique distinctions in some of the Austronesian languages of Indonesia. Special attention has been given to the relative degree of coreness (measured in terms of a core index) and to the borderline cases.

Arguments having intermediate core properties, called 'semi-core' arguments, are encountered even in languages such as Indonesian, which show a clear core-oblique distinction. This property of semi-coreness is associated not only with the stimulus argument of a 
cognition/emotion verb such as suka 'like' (Indonesian) and yaro 'love' (Palu'e), but also with an agent of an action verb, as in the Indonesian di-verbs. In other languages of eastern Indonesia, it can also be associated with the goal argument of the Applicative 2 construction.

Identifying arguments as syntactically core or oblique is often a problem. This is partly due to the incorrect pre-conception that such a distinction is taken as categorical. This is also partly due to a lack of (or limited) evidence for such a distinction in a given language. This itself may be due to the absence of detailed grammatical descriptions and good methodology for assessing the distinction. Simple core index calculation as proposed in this paper is one step forward in this respect. Core index calculation has been proven a useful tool by which uncertainty in the core vs. oblique question can be resolved with confidence. It has been shown that overt coding of NP vs. PP is often not helpful, since an argument of intermediate status can be either NP or PP, or both. It has also been shown that applicativisation (with overt applicative morphology), as in Taba, does not always result in clear core promotion. Passivisation is often not a good test for core vs. oblique distinction, particularly in the isolating languages of Flores, because it does not apply exclusively to transitive objects. The core index analysis takes the leading idea that core properties are clustered, with certain arguments more prototypically core than others, and the core vs. oblique distinction is the distinction of two ends along a continuum with certain arguments that are clearly neither cores nor obliques; they are semi-cores.

\section{Theoretical implications}

The evidence for the existence of semi-core arguments discussed in this paper poses a challenge for a theory of 'surface' grammatical relations. Semi-coreness particularly does not fit comfortably with a theory that posits or imposes discrete relations, particularly a clear-cut distinction between objects and obliques. ${ }^{29}$ One current syntactic theory that makes use of the terms SUBJECT, OBJECT and OBLIQUE as discrete surface grammatical relations/functions is LFG. This is, for example, reflected in the LFG notion that such grammatical functions can be captured by using binary features, such as $[+/-$ o] and [+/- r] (Bresnan, 2001; Bresnan \& Kanerva, 1989), [+/- subject] and [+/- oblique] (A. Alsina, 1996), or [+/- Term] (Arka 2003). I will not discuss the mechanism of how arguments receive their surface grammatical functions, as that could be quite lengthy. However, I wish to point out that 'semi-coreness' cannot be easily captured in LFG, at least in the current conception of the theory with which I am familiar.

A binary feature [+/- oblique] (cf., A. Alsina, 1996) or [+/- Term] (Arka 2003), for example, implies the idea that an argument is either oblique or core. However, we have observed that the Actor of the di-verb in Indonesian can be neither oblique nor core. Put differently, when an Actor is not oblique, it does not automatically mean that it is core. If one adopts this discrete conception, one will be forced wrongly to label what is empirically a semicore argument either as a core or as an oblique (sometimes quite arbitrarily).

Musgrave $(2001 ; 2008)$ discusses the stimulus argument of a verb like suka in Indonesian within LFG. He concludes that it is neither SUBJ nor OBJ. The most plausible alternative, he claims, is that it is to be classified as a kind of restricted object, called OBJ-theta in LFG. OBJ-theta is the second object of a ditransitive verb. This analysis is forced by the theory, which he admits is too restrictive in the version that is currently formulated. However, Musgrave further shows that such an analysis is unsatisfactory empirically, in terms of the Indonesian data. The stimulus NP shows properties different from the second object of a ditransitive in Indonesian. He then concludes and prefers an analysis in which the stimulus NP 
is classified as a regular (transitive) OBJ. However, he conceives two kinds of grammar in Indonesian: one that regulates the standard/formal register (characterized by prefixed transitive verbs) and the other that regulates the informal register (characterized by unprefixed transitive verbs). Emotion/cognition verbs (in both registers) are regulated by the second grammar, in which case the stimulus NP is a regular OBJ. His account, he admits, has one oddity (which is not well explained): emotion/cognition verbs require applicative morphology in order to form a prefix verb (e.g., as in the passive di-), even in the informal register.

In contrast, my analysis in this paper shows that the stimulus NP is not a core, as evidenced by its core index. In this analysis, it is expected that the stimulus NP will not be identified as any of the core members (SUBJ, OBJ, or OBJ-theta) because it is a semi-core argument (in both registers). The present analysis also predicts that if this stimulus NP is to be realized as grammatical SUBJ (which has to be a core), it must be associated with a verb having applicative morphology since the stimulus has to be promoted to core status first in Indonesian. This analysis is simpler than Musgrave's, and, crucially, the presence of applicative morphology is accounted for.

The question remains as to how semi-coreness can be couched within LFG. There are at least two ways; both may have far-reaching consequences within the theory. The first one, also discussed (and rejected) in Musgrave (2008) is to allow an expansion of the inventory of grammatical functions. For example, a category of semi-OBJ, different from OBJ and OBJtheta, could perhaps be introduced as the realisation of the semi-core argument. Such a proliferation of surface function classification is not attractive, however. The semi-core class itself is often a negatively defined class (i.e., neither core nor oblique), so that verbs it is associated with may not form a well-defined class. Note that semi-core status may be also associated with A arguments of action verbs. In addition, it remains a problem as to how the precise mapping for semi-cores mechanism fits in with the standard mapping theory, using binary features, that is currently adopted in LFG. As pointed out by Musgrave, the introduction of one new feature with positive and negative values would yield more than one new class of function.

The second approach is to adopt a simplified, surface grammatical function classification, where only subject and complement functions are differentiated. This is a traditional distinction, which is also made explicit in the feature structure of HPSG (Pollard \& Sag, 1994; I. A. Sag, Wasow, \& Bender, 2003). This approach is attractive. Firstly, the distinction between subject and complement is more discrete than the distinction between core and non-core/oblique. This discreteness is empirically supported, at least by the Indonesian languages that have subjecthood; as discussed in this paper (and elsewhere). Secondly, the complement function itself is a broad natural class. It encompasses cores as well as obliques. Crucially, the degree of coreness/obliqueness is not a defining criterion for complement class membership. One is thus not forced to sub-classify an argument into an 'incorrect' relation. The complement analysis also does not prevent one from making a sub-classification of complements, e.g., into a core complement, a semi-core complement, or an oblique complement. The idea that complements include members that have graded degrees of coreness/obliqueness can easily be accommodated in this analysis. ${ }^{30}$

The gradient nature of the cline from core to oblique/adjunct also appears to pose a challenge to Dixon's Basic Linguistic Theory (BLT) (R.M.W Dixon, 1979; 1994, 2010), particularly with regard to Dixon's label E. Recall that E is defined as 'extension to core, a non- 
A non-O for an extended transitive, or second obligatory argument in an extended intransitive' (Dixon 1994:122-3). In Dixon's classification, since suka 'like' is a two-place predicate, the semi-core stimulus NP of suka 'like' (see 4.1) would be either E or O. Analysing it as an O means that it is analysed in the same way as the $\mathrm{O}$ of the actual AV transitive menyukai, which is a prototypical core. Analysing it as an E means that it is analysed in the same way as the stimulus PP of suka, which is highly oblique and whose whole structure is syntactically intransitive. However, we have proven that the stimulus NP of suka is neither typical core O (of a transitive structure), nor Oblique $\mathrm{E}$ (of an intransitive structure).

\section{Further research}

It is worth highlighting the question as to why languages make core-object distinctions clear or unclear in certain cases. ${ }^{31}$ To answer this, one must look at the coding or morphosyntactic resources available across languages and at the range of variables related to or motivating coreoblique distinctions, if such distinctions are made. In languages where there is limited or no evidence for such distinctions made, then one must investigate the equivalent variables and the related expressions in these languages.

It is now recognized that semantic and pragmatic variables interact in a complex way to determine transitivity (Hopper \& Thompson, 1980). A satisfactory account for (syntactic) semicoreness/obliqueness must take into account these non-syntactic factors. Thompson (1997) shows that the core-oblique distinction is reflected in the information structure of languages like English: cores are more likely to track discourse participants than obliques. A discourse study in Japanese (Nakayama \& Ichihashi-Nakayama, 1994), however, does not show the positive correlation between the core-oblique distinction and information structure. For Indonesian, there has been some work on the pragmatic motivation behind the different expressions of core arguments in this language by Purwo (1989) and Uhrbach (1988), ${ }^{32}$ but not on the pragmatics of other semi-core arguments. There has been no research done on the pragmatics of core-obliques and borderline cases in Balinese either. ${ }^{33}$ Information on cores and obliques in the literature on the Austronesian languages mentioned in this paper is also generally limited to overt morphosyntactic coding.

My own research on topic continuity of semi-core arguments in Indonesian show that non-SUBJ core, semi-core, and oblique arguments show no clear difference in information structure, at least when measured in terms of their referential distance (RD). Measurement of RD shows degree of anaphoric referential continuity (see (Talmy Givón, 1983) for extensive discussion). The measurement is done by assigning a $\mathrm{RD}$ value of 1 or 2 when the most recent reference of an argument was made in one or two preceding clauses. The frequency of occurrences is tallied. A highly topical argument will have high percentage of RD of 1-2.

The RD values and the statistics of the stimulus arguments of suka 'like' in Indonesian are shown in Table 11. Recall that from discussion in 4.1 we know that the stimulus argument of [menyukai NP], [suka NP] and [suka PP] are core object, semi-core, and oblique, respectively. The stimulus SUBJ is also included in the table for comparative discussion. As clearly seen from the statistics, the percentage of the RD 1 and 2 (combined; shaded cells in Table 11) of core object, semi-core, and oblique arguments are within $40 \%-46 \%$ range, meaning that these three non-SUBJ arguments are generally not topical and that their degree of topicality is not significantly different. In contrast, the stimulus NP SUBJ is highly topical, with RD of 1 in $72 \%$ of the cases. 


\begin{tabular}{|c|c|c|c|c|c|c|c|}
\hline & \multicolumn{2}{|c|}{ CORE OBJECT } & \multicolumn{2}{|l|}{ Semi-core } & \multicolumn{2}{|l|}{ Oblique } & SUBJ \\
\hline $\mathrm{RD}$ & \multicolumn{2}{|c|}{ Menyukai NP } & \multicolumn{2}{|l|}{ Suka NP } & \multicolumn{2}{|l|}{ Suka PP } & $\begin{array}{l}\text { NP (Pro)sukai } \\
\text { /disukai }\end{array}$ \\
\hline 0 & \multicolumn{2}{|l|}{$\begin{array}{l}17 \\
(50 \%)\end{array}$} & \multicolumn{2}{|l|}{$\begin{array}{l}23 \\
(48 \%)\end{array}$} & \multicolumn{2}{|l|}{$\begin{array}{l}12 \\
(41 \%)\end{array}$} & $\begin{array}{l}5 \\
(28 \%)\end{array}$ \\
\hline 1 & $\begin{array}{l}12 \\
(35 \%)\end{array}$ & \multirow{2}{*}{$(41 \%)$} & $\begin{array}{l}19 \\
(40 \%)\end{array}$ & \multirow[t]{2}{*}{$(46 \%)$} & $\begin{array}{l}9 \\
(31 \%)\end{array}$ & \multirow{2}{*}{$(44 \%)$} & $\begin{array}{l}13 \\
(72 \%)\end{array}$ \\
\hline 2 & $\begin{array}{l}2 \\
(6 \%)\end{array}$ & & $\begin{array}{l}3 \\
(6 \%)\end{array}$ & & $\begin{array}{l}4 \\
(14 \%)\end{array}$ & & \\
\hline$>/=3$ & \multicolumn{2}{|l|}{$\begin{array}{l}3 \\
(9 \%) \\
\end{array}$} & \multicolumn{2}{|l|}{$\begin{array}{l}3 \\
(6 \%) \\
\end{array}$} & \multicolumn{2}{|l|}{$\begin{array}{l}4 \\
(14 \%)\end{array}$} & \\
\hline Total & \multicolumn{2}{|l|}{34} & \multicolumn{2}{|l|}{48} & \multicolumn{2}{|l|}{29} & 18 \\
\hline
\end{tabular}

Table 11. RD of different types of stimulus arguments of suka

The study just presented above is limited on non-core arguments of the verb suka in Indonesian. There is certainly still much to be investigated concerning the pragmatics of semi-coreness across similar constructions in Indonesian, and also in other languages.

Nevertheless, there is one thing worth noting that emerges from the research reported in this paper: a pragmatically motivated distinction of core-oblique is evident in the alternation of oblique $\leftrightarrow$ subject rather than of oblique $\leftrightarrow$ object. There are, in fact, cases of prohibited alternation of oblique and core object (see examples from Palue, Pendau, Manggarai, and Rongga). This suggests that a highly prominent pragmatic function of Topic might have been grammaticized and tied to core-subject (Bresnan, 2001; Talmy Givón, 1979; Li \& Thompson, 1976; Shibatani, 1991). Pragmatic prominence, in particular high topicality, then becomes the only constraint and motivation on licensing promotion of a role to core status. Objects or semiobjects are not associated with this grammaticized pragmatic function and do not attract or license promotion of a non-core role to (semi-)core status. The nature of the pragmatic difference between objects and the other non-subject functions (semi-objects, non-typical obliques, and real obliques) in the Austronesian languages of Indonesia is a matter for further investigation. Research of the types outlined in Givon (1983), Dryer (1994), and Thompson (1997) is certainly worth undertaking for core and non- or semi-core arguments across the Austronesian languages of Indonesia.

A semantically motivated distinction of core-oblique is often encountered in the alternation of an oblique and a highly core object. The difference is typically associated with the affected meaning as seen in the load/spray verbs in English, or with additional volition and a

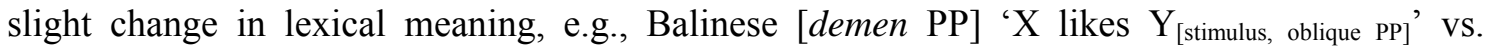
demen-in NP ' $\mathrm{X}$ makes.love.with $\mathrm{Y}_{\text {[stimulus, coreNP]. }}$ Other meanings noted as being involved in core alternations include aspects (completed vs. non-completed), animacy, and (temporary/permanent) transfer of ownership, i.e., trivalent 'give-like' verbs of the type found in Kimaragang (Paul Kroeger, 2005: 420-421), Indonesian, Balinese, and many other languages (Kittilä, 2007, 2008). A close scrutiny of other verb types could reveal further important meanings motivating the core alternation.

Finally, there may be no clear semantic motivation for the distinction. Sociolinguistic factors could be involved. In Indonesian, when an argument can be realized as a core, semi-core, or oblique, the distinction is often semantically tenuous. For example, the semantic difference in 
Indonesian between [suka NP] 'like NP' (semi-core) and [suka PP] 'like PP' (non-core) is hard to pin down. The choice is often stylistic, which is a personal matter. But, the difference between [suka NP] (unaffixed) (semi-core) and [MeN-suka-i NP] (affixed) (core) has been recognized to be register-related, informal vs. formal/standard Indonesian.

A systematic study is indeed needed to disentangle the range of inter-related variables involved in the distinction of core, semi-core, and oblique arguments. This distinction is just one of the phenomena arguably showing gradient properties in grammar. The investigation of grammatical gradience and its precise analysis/modelling has been, and will remain, of theoretical and typological interest in linguistics for years to come.

\section{References}

Aarts, B. (2007). Syntactic gradience. Oxford: Oxford University Press.

Aldridge, E. (2009). Antipassive in Austronesian alignment change. In D. Jonas, J. Whitman \& A. Garrett (Eds.), Grammatical change: origins, nature, outcomes. Oxford: Oxford University Press.

Alsina, A; Mohanan, K. P.; \& Mohanan, T. (2005). How to get rid of the COMP. Paper presented at the Proceedings of the LFG05 Conference.

Alsina, A. (1996). The role of argument structure in grammar: Evidence from Romance. Stanford: CSLI.

Andrews, A. D. (2007). The major functions of the noun phrase. In T. Shopen (Ed.), Language Typology and Syntactic Description (Second edition ed., Vol. 1, pp. 132-223). Cambridge, England: Cambridge University Press.

Arka, I W. (2003). Balinese morphosyntax: A lexical-functional approach. Canberra: Pacific Linguistics.

Arka, I W. (2005). Challenges and prospect of maintaining Rongga: a preliminary ethnographic report. In I. Mushin (Ed.), Proceedings of the 2004 Conference of the Australian Linguistics Society. http://deneb.library.usyd.edu.au:8080/handle/2123/138.

Arka, I W. (2008). Voice and being core: Evidence from (eastern) Indonesian languages. In P. K. Austin \& S. Musgrave (Eds.), Voice and grammatical relations in Austronesian languages (pp. 183-227). Stanford: CSLI.

Arka, I W. \& Kosmas, J. (2005). Passive without passive morphology? Evidence from Manggarai. In I W. Arka \& M. D. Ross (Eds.), The many faces of Austronesian voice systems: some new empirical studies (pp. 87-117). Canberra: Pacific Linguistics.

Arka, I W. \& Manning, C. (2008). Voice and grammatical relations in Indonesian: A new perspective. In P. K. Austin \& S. Musgrave (Eds.), Voice and grammatical relations in Austronesian Languages (pp. 45-69). Stanford: CSLI.

Arka, I W; \& Simpson, J. (2008). Objective voice and control into subject clauses in Balinese. In P. K. Austin \& S. Musgrave (Eds.), Voice and grammatical relations in Austronesian Languages (pp. 70-127). Stanford: CSLI.

Arka, I W, \& Wechsler, S. (1996). Argument structure and linear order in Balinese binding. In M. Butt \& T. H. King (Eds.), The proceedings of the LFG'96 Conference. Stanford: CSLI, http://csli-publications.stanford.edu/LFG/1/toc-lfg1.html.

Baird, L. (2002). A grammar of Keo: An Austronesian language of East Nusantara. (PhD thesis), ANU, Canberra. 
Baker, M. C. (1988). Incorporation: A theory of grammatical function changing. Chicago: University of Chicago Press.

Bell, S. (1983). Advancements and ascensions in Cebuano. In D. M. Perlmutter (Ed.), Studies in relational grammar 1 (pp. 143-218). Chicago: University of Chicago Press.

Bowden, J. (2001). Taba: Description of a south Halmahera language. Canberra: Pacific Linguistics.

Bresnan, J. (2001). Lexical functional syntax. London: Blackwell.

Bresnan, J, \& Kanerva, J. M. (1989). Locative inversion in Chichewa: A case study of factorization in grammar. Linguistic Inquiry, 20, 1-50.

Bresnan, J. \& Moshi, L. (1990). Object asymmetries in comparative Bantu Syntax. Linguistic Inquiry, 21(2), 147-185.

Chomsky, N. (1981). Lectures on government and binding theory. Dordrecht: Foris.

Chomsky, N. (1995). The minimalist program. Cambridge, Mass.: The MIT Press.

Chung, S. (1976). On the subject of two passives in Indonesian. In C. N. Li (Ed.), Subject and topic (pp. 57-99). NewYork: Academic Press.

Cole, P.; Hermon, G. \& Yanti. (2008). Voice in Malay/Indonesian. Lingua(118), 1500-1553.

Comrie, B. (1978). Ergativity. In W.P. Lehman (Ed.), Syntactic typology: Studies in the phenomenology of language (pp. 329-394). Austin: University of Austin Press.

Comrie, B. (2005). Towards a typology of ditransitive constructions. Paper presented at the the Sixth Congress of the Association for Linguistic Typology, Padang, Indonesia.

Cooreman, A; Fox, B. \& Givón, T. (1984). The discourse definition of ergativity. Studies in language, 8, 8-134.

Croft, W. (2001). Radical construction grammar. Oxford: Oxford University Press.

Croft, W. (2003). Typology and universals (second edition). Cambridge: Cambridge University Press.

Dalrymple, M. (1993). The syntax of anaphoric binding. Stanford: CSLI Publications.

Dalrymple, M. (2001). Lexical Functional Grammar. San Diego: Academic Press.

Dalrymple, M. \& Lødrup, H. (2000). The grammatical functions of complement clauses. Paper presented at the Proceedings of the LFG00 Conference.

De Guzman, V. P. (1988). Ergative analysis for Philippine languages: An analysis. In McGinn (Ed.), Studies in Austronesian Linguistics (pp. 1988:1323-1345.). Athens, Ohio: Center for International Studies.

Dixon, R.M.W. (1979). Ergativity. Language, 55, 59-138.

Dixon, R.M.W. (1994). Ergativity. Cambridge, England: Cambridge University Press.

Dixon, R.M.W. (2010). Basic Linguistic Theory (Vol. 2). Oxford: Oxford University Press.

Dixon, R.M.W. (1997). The rise and fall of languages. Cambridge: Cambridge University Press.

Donohue, M. (1999). A Grammar of Tukang Besi. Berlin: Mouton de Gryuter.

Donohue, M. (2002). Voice in Tukang Besi and the Austronesian focus system. In F. Wouk \& M.D. Ross (Eds.), The history and typology of western Austronesian voice systems (pp. 81-99). Canberra: Pacific Linguistics. 
Donohue, M. (1998). Transitivity in Tukang Besi. Studies in Language, 22(1), 83-111.

Donohue, M. (2005). The Palu'e passive: From pragmatic construction to grammatical device. In I W. Arka \& M. D. Ross (Eds.), The many faces of Austronesian voice systems: Some new empirical studies (pp. 59-85). Canberra: Pacific Linguistics.

Dowty, D. (1991). Thematic proto-roles and argument selection. Language, 67, 547-617.

Dowty, D. (2003). The dual analysis of adjuncts/complements in Categorial Grammar. In E. Lang, C. Maienborn \& C. Fabricius-Hansen (Eds.), Modifying adjuncts (pp. 35-66). Berlin: Mouton de Gruyter.

Dryer, M. S. (1986). Primary objects, secondary objects, and antidative. Language, 62(4), 808845 .

Dryer, M. S. (1994). The discourse function of the Kutenai inverse. In T. Givón (Ed.), The pragmatics of de-transitive voice (pp. 65-99). Amsterdam: John Benjamins.

Florey, M. (2001). Verb and valence in Alune. In P. Austin, B. J. Blake \& M. Florey (Eds.), La Trobe Papers in Linguistics (Vol. 11, pp. 73-120). Melbourne: La Trobe University.

Foley, W. A. (1998). Symmetrical voice systems and precategoriality in Philippine Languages. Paper presented at the workshop on voice and grammatical functions in Austronesian languages, LFG98, Sydney.

Foley, W. A. (2008). The place of Philippine languages in a typology of voice systems. In P. K. Austin \& S. Musgrave (Eds.), Voice and grammatical relations in Austronesian languages (pp. 22-44). Stanford: CLSI.

Foley, W. A. \& Van Valin, R. D. (1984). Functional syntax and universal grammar. Cambridge: Cambridge University Press.

Frantz, D. G. (1981). Grammatical relations in universal grammar. Bloomington: Indiana University Linguistics Club.

Gerdts, D. B. (1988). Antipassives and causatives in Ilokano: Evidence for an ergative analysis. In McGinn (Ed.), Studies in Austronesian Linguistics (pp. 295-321.). Athens, Ohio: Center for International Studies.

Givón, T. (1983). Introduction. In T. Givón (Ed.), Topic continuity in discourse: a quantitive cross-language study (pp. 1-41). Amsterdam: John Benjamins.

Givón, T. (1979). From discourse to syntax: Grammar as a processing strategy. In T. Givón (Ed.), Syntax and semantics. Vol. 12: Discourse and syntax (pp. 81-112.). New York: Academic Press.

Haspelmath, M. (2007). Ditransitive alignment splits and inverse alignment. Functions of Language 14 (1), 79-102.

Himmelmann, N. P. (2005). The Austronesian languages of Asia and Madagascar: Typological characteristics. In K. A. Adelaar \& N. P. Himmelmann (Eds.), (pp. 110-181). London: Routledge.

Hopper, P. \& Thompson, S. (1980). Transitivity in grammar and discourse. Language, 56, 251299.

Horie, K. (2000). Core-oblique distinction and nominalizer choice in Japanese and Korean. Studies in Language, 24(1), 77-102.

Jauhary, E. (2000). Pasif bahasa Bima. (MA thesis), Udayana University, Denpasar. 
Jeong, Y. (2007). Applicatives: Structure and interpretation from a minimalist perspective. Amsterdam: John Benjamins Publishing Co.

Katagiri, M. (2005). Voice, ergativity and transitivity in Tagalog and other Philippine languages: a typological perspective. In I W. Arka \& M. D. Ross (Eds.), The many faces of Austronesian voice systems: Some new empirical studies. Canberra: Pacific Linguistics.

Keenan, E. L. \& Comrie, B. (1977). Noun phrase accessibility and universal grammar. Linguistic Inquiry, 8, 63-99.

Kittilä, S. (2007). On the encoding of transitivity-related features on the indirect object. Functions of Language, 14(1), 149-164.

Kittilä, S. (2008). Differential Object Marking revisited: Concerning the animacy effects on the encoding of Goals. Linguistic Typology. Linguistic Typology, 12(2), 245-268.

Kosmas, J. (2000). Argumen aktor dan pemetaannya dalam bahasa Manggarai. (MA thesis), Universitas Udayana, Denpasar.

Kroeger, P. (1993). Phrase structure and grammatical relations in Tagalog. Stanford: CSLI Publications.

Kroeger, P. (2005). Kimaragang. In K. A. Adelaar \& N. P. Himmelmann (Eds.), The Austronesian languages of Asia and Madagascar (pp. 397-428). London: Routledge.

Li, C. N. \& Thompson, S. (1976). Subject and Topic: A new typology of Language. In C. N. Li (Ed.), Subject and Topic (pp. 457-490). New York: Academic Press.

Manning, C. D. (1996). Ergativity: Argument structure and grammatical relations. Stanford: CSLI.

Marantz, A. (1993). Implications of asymmetries in double object constructions. In S. A. Mchombo (Ed.), Theoretical aspects of Bantu grammar 1 (pp. 113-151). Stanford: CSLI.

Margetts, A. \& Austin, P. K. (2007). Three-participant events in the languages of the world: towards a cross-linguistic typology. Linguistics, 45 (3), 393-451.

McCune, K. (1979). Passive function and the Indonesian passive. Oceanic Linguistics, 18, 119169.

McGinnis, M. (2001). Variation in the phase structure of applicatives. Linguistic variation Yearbook 1, 105-146.

Mithun, M. (1994). The implications of ergativity for a Philippine voice system. In B. Fox \& P. J. Hopper (Eds.), Voice: Form and Function (pp. 247-277). Amsterdam/Philadelphia: John Benjamins.

Musgrave, S. (2001). Non-subject arguments in Indonesian. (PhD thesis), Melbourne University.

Musgrave, S. (2008). The grammatical function OBJ in Indonesian. In P. Austin \& S. Musgrave (Eds.), Voice and grammatical relations in Austronesian Languages. Stanford: CSLI.

Nakayama, T. \& Ichihashi-Nakayama, K. (1994). Discourse perspective for core-oblique distinction in Japanese. Santa Barbara Papers in Linguistics, 5, 158-177.

Pastika, I Wayan. (1999). Voice selection in Balinese narrative discourse. ( $\mathrm{PhD}$ thesis), Australian National University. 
Payne, T. E. (1982). Role and reference related subject properties and ergativity in Yup'ik Eskimo and Tagalog. Studies in Language, 6(75-106).

Peterson, D. A. (2007). Applicative constructions. Oxford: Oxford University Press.

Pollard, C. \& Sag, I. A. (1994). Head-driven phrase structure grammar. California: CSLI Publications, Stanford and University of Chicago Press.

Purwo, B.K. (1989). Voice in Indonesian : A discourse study. In B. K. Purwo (Ed.), Serpih serpih telaah pasif bahasa Indonesia (pp. 344-442). Yogyakarta: Kanisius.

Pykkänen, L. (2008). Introducing arguments. Cambridge Massachusetts: The MIT Press.

Quick, P. (2007). A grammar of the Pendau language of Central Sulawesi, Indonesia. Canberra: Pacific Linguistics.

Ross, M. D. (2002). The history and transitivity of Western Austronesian voice and voice marking. In F. Wouk \& M. D. Ross (Eds.), The history and typology of Western Austronesian Voice Systems (pp. 17-62). Canberra: Pacific Linguistics.

Ross, M. D. (2006). The argument structure of undergoer voice clauses in Formosan and other Philippine-type languages. Paper presented at the AFLA 13, Taiwan.

Sag, I. A; Wasow, T. \& Bender, E. M. (2003). Syntactic theory: a formal introduction (second edition). Stanford: CSLI.

Sag, I. \& Pollard, C. (1991). An integrated theory of complement control. Language, 67, 63113.

Sawardi, F.X. (2000). Argumen kompleks bahasa Lio (Complex arguments in Lio). (MA thesis), Udayana University, Denpasar.

Schachter, P. (1977). Reference-related and role-related properties of subjects. In P. Cole \& J. M. Sadock (Eds.), Syntax and semantics Vol. 8: Grammatical Relations (pp. 279-306). New York: Academic Press.

Sedeng, I N. (2000). Kalimat kompleks dan relasi gramatikal bahasa Sikka. (Master Thesis), Universitas Udayana, Denpasar.

Sells, P. (1988). Thematic and grammatical hierarchies: Albanian reflexivization. In H. Borer (Ed.), In Proceedings of the Seventh West Coast Conference on Formal Linguistics (pp. 293-303). Stanford: Stanford Linguistics Association, Stanford University.

Shibatani, M. (1991). Grammaticization of topic into subject. In E. C. Traugott \& B. Heine (Eds.), Approaches to grammaticalization (Vol. 2, pp. 93-133). Amsterdam: John Benjamins Publishing Company.

Simpson, J. (1991). Warlpiri-morpho syntax. Dordrecht: Kluwer.

Sneddon, J. N. (1996). Indonesian reference grammar. St Leonards: Allen and Unwin.

Teng, S. F. (2005). Grammatical relations in Puyuma. In I W. Arka \& M. D. Ross (Eds.), The many faces of Austronesian voice systems: Some new empirical studies. Canberra: Pacific Linguistics.

Teng, S. F. (2008). A reference grammar of Puyuma, an Austronesian language of Taiwan. Canberra: Pacific Linguistics.

Thompson, S. A. (1997). Discourse motivations for the core-oblique distinction as a language universal. In A. Kamio (Ed.), Directions in functional linguistics (pp. 59-82). Amsterdam: John Benjamins. 
Uhrbach, AMy. (1988). Topicality and verbs encoding two arguments in bahasa Indonesia. In R. Mc.Ginn (Ed.), Studies in Austronesian Linguistics 76 (pp. 455-473). Ohio: Ohio University Monographs in International Studies.

Vamarasi, M. K. (1999). Grammatical relations in Bahasa Indonesia. Canberra: Pacific Linguistics.

Van Valin Jr., R. D. \& LaPolla, R. J. (1999). Syntax. Structure, meaning and function. Cambridge: Cambridge University Press.

Van Valin Jr., R. D. \& LaPolla, R. J. (1997). Syntax. Structure, meaning and function. Cambridge: Cambridge University Press.

Verheijen, J.A.J. (1977). The lack of formative in affixes in the Manggarai language. NUSA, 5, 35-37.

Webelhuth, G. (Ed.). (1995). Government and binding theory and the minimalist program. Oxford: Blackwell.

Wechsler, S. (1999). HPSG, GB, and the Balinese bind. In A. Kathol, J.-P. Koenig \& G. Webelhuth (Eds.), Lexical and constructional aspects of linguistic explanation (pp. 179195). Stanford: CSLI Publications.

Wechsler, S. \& Arka, I W. (1998). Syntactic ergativity in Balinese: An argument structure based theory. Natural Language and Linguistic Theory, 16, 387-441.

Wouk, F. (2002). Voice in the languages of Nusa Tenggara Barat. In F. Wouk \& M. D. Ross (Eds.), The history and typology of western Austronesian voice systems (pp. 285-309). Canberra: Pacific Linguistics.

\section{NOTE}

*I gratefully acknowledge the support of the ARC Discovery Grant (DP0877595), the NSF grant (BCS0617198), the Humboldt Georg Forster Fellowship and the TUFS Visiting Professorship. An earlier version of this paper was presented as a keynote address at the International ALT VI (Association of Linguistic Typology) conference in Padang, Indonesia on 25 July 2005. I thank John Bowden, Peter Cole, Mark Donohue, Andy Pawley, Malcolm Ross, Matt Shibatani, Jane Simpson, Jae Jung Song, Anna Siewierska, and the audience at the ALT conference for their questions, comments, and suggestions. All remaining errors are mine.

\footnotetext{
${ }^{1}$ In contrast, semantic/pragmatic/global transitivity is, however, clearly a matter of degree (Hopper \& Thompson, 1980).

${ }^{2}$ Following Sag and Pollard (I. Sag \& Pollard, 1991), I take this useful term as a way of avoiding controversial terms such as 'proposition' and 'event'.

${ }^{3}$ Two types of distinctions of objects are proposed, depending on the alignment of $P$ with respect to $G$ and $\mathrm{T}$ : i) direct vs. indirect objects ( $\mathrm{P}=\mathrm{T}$ vs. $\mathrm{G}$ ) and ii) primary vs. secondary objects ( $\mathrm{P}=\mathrm{G}$ vs. $\mathrm{T}$ ); see Dryer (1986) for detailed discussion.

${ }^{4}$ Abbreviations used in the glosses of the examples in this paper: 1 'first person', 2 'second person', 3 'third person', A 'attitudinal deictic', ABS 'absolutive', AM 'Ambonese Malay', APPL 'applicative', ART 'article', AV 'agentive voice', BEN 'benefactive', D 'dative', DEF 'definite', DETR 'detransitivising', FUT 'future', INTF 'intensifier', IR 'irrealis', LOC 'locative', NOM/N 'nominative', OBJ 'object', OP 'object prefix', POSS 'possessive', PROX 'proximal', p(l) 'plural', PT 'primary transitive', $\mathrm{QF}$ 'quantifier float', $\mathrm{RE}(\mathrm{AL})$ 'realis', s/SG 'singular', SF 'stem prefix former', TZ 'transitiviser', UV 'undergoer voice',

${ }^{5} \mathrm{OBJ}_{\theta}$ or OBJ-theta is a kind of object that is thematically restricted, which cannot alternate to become SUBJ (e.g., in passivisation). It is equivalent to what Dryer (1986) calls secondary object or what is traditionally called second OBJ.
} 
${ }^{6}$ There are two notes for (X)COMP. First, the notation X in (X)COMP means that the complement clause (COMP) contains a controlled (SUBJ) argument. Second, it has been shown that (X)COMP in Balinese may show core properties, e.g., it may alternate with SUBJ in Undergoer voice (Arka \& Simpson, 2008). The proposal to eliminate the COMP function is discussed in Alsina, Mohanan, and Mohanan (2005).

7 The defining properties shown in Table 2 are the most common cross-linguistic generalizations. It should be noted that there may be 'language-specific exceptions'. For example, while adjuncts in English are generaly in line with the properties shown in the table, there are instances where they can be obligatory. This kind of 'subcategorised adjunct' (David Dowty, 2003:39) is exemplified below with the verb behave:

a. Johnny behaved badly.

b.* Johnny behaved. (Acceptable only with a different meaning for behave)

${ }^{8}$ It should be noted that the core index calculation assumes that all the core properties are roughly of equal weight. I have investigated whether the core properties in Indonesian and Balinese (see Tables 3 and 4) may have some kind of relative ranking, but found no conclusive result. It remains to be investigated whether there is evidence for relative prominence among core properties.

If there is such evidence, properties that are more prominent can be assigned higher values. Then, taking into account of different weights, the core index can be calculated in the same way resulting in the same range of 1.00 (definitely core) to 0.00 (definitely non-core). For example, suppose that there are 10 core properties, each has its own rank with the top one being 10, and the lowest one being 1 . If an argument satisfies all of the core properties, the index will still be 1.00 (i.e., a maximum value of 55 $(=10+9+8+7+6+5+4+3+2+1)$ divided by the possible maximum value of 55 .

For the purposes in this paper, in the absence of evidence for relative weight of core properties, I use a simpler method in assigning an equal weight to each core property. In theory, I believe, the complex method calculating an index with core properties having different weights would basically lead to the same conclusions, e.g., the agent of the AV structure in Balinese and Indonesian will have a maximum index of 1.00 and the agent of a passive structure will have a very low core index.

${ }^{9}$ There is a semantic constraint for this in Balinese (Arka, 2003; Arka \& Simpson, 2008). The choice of the controller (subject/object) depends on the meaning/type of the control verb, e.g., for the influence type such as 'ask' the askee, not the asker, is the controller (William A. Foley \& Van Valin, 1984; Pollard \& Sag, 1994; I. Sag \& Pollard, 1991) .

${ }^{10}$ Examples of this type include baang 'let, allow' where the complex argument behaves like the third core argument in Balinese.

${ }^{11}$ Balinese binding is discussed in depth in (Arka, 2003; Arka \& Wechsler, 1996; Wechsler, 1999; Wechsler \& Arka, 1998) .

${ }^{12}$ Note that patient and theme are considered to be of equal rank and no differentiation is made between these subtypes roles in the universal thematic hierarchy, e.g., in a version proposed by Bresnan and Kanerva (1989).

${ }^{13}$ In the 'symmetrical voice' analysis of Balinese (2003), the UV alternation is not passivisation: UV, unlike passive, does not demote $\mathrm{A}$ to Oblique status. This might give the impression that $\mathrm{A}_{\mathrm{UV}}$ and $\mathrm{A}_{\mathrm{AV}}$ are of equal core status. On the analysis that UV is a kind of passive, however, the finding here is what might have been expected.

14 'Extraction' is regarded as a property of core in Indonesian by Musgrave (2008) (for unprefixed verbs). It is not included in Table 4, as it applies only in non-standard Indonesian. In standard Indonesian, extraction is only possible with the subject. While it could be found in informal (spoken) Indonesian, the judgment of its unacceptability varies and is often in dispute. The inclusion of the extraction property would not significantly affect the core index shown in Table 4 (and the analysis based on the table). The only difference would be the core index of the A of the UV verb, which would be slightly lower, as this A argument cannot be extracted even in the non-standard Indonesian. This means that it is slightly less core that the one now shown in the table even though it is still a marginal core argument.

${ }^{15}$ A 'passive' di- verb can be used in the imperative to encode politeness, e.g. diambil saja! 'just take it'. However, this $d i$ - verb is most likely not a syntactically passive verb because when the agent is made explicit in PP, the imperative is not acceptable, e.g. *Diambil saja oleh kamu! 'Take it, by you!' See discussion in 4.2, where a di-verb could be 'transitive-like' with the A being 'core-like'.

${ }^{16}$ The constraint responsible for (a) symmetric variations in function alternation of the two objects has been of interest across different theoretical frameworks. In LFG, it is captured by the AOP (Asymmetry 
Object Principle) (Bresnan \& Kanerva, 1989; Bresnan \& Moshi, 1990). A language that allows only one object to alternate with subject is referred to as a language with asymmetrical objects. The argumentstructure based analysis of the AOP in the Indonesian languages of Nusa Tenggara is discussed in Arka (2008). Parameterized properties in voice system and object doubling are also discussed in Foley (1998). In Chomskyan Government Binding theory, the (a)symmetries explained in terms of different phrasal configurations of direct and indirect objects in relation to Case, theta-theory and government principles (Baker, 1988; Marantz, 1993). Currently, the (a)symmetries are accounted for in terms of structural differences between High and Low Applicatives within phase-driven mechanism in Minimalism (McGinnis, 2001; Pykkänen, 2008). Theoretical and typological problems of these analyses are discussed in Peterson (2007) and Jeong (2007).

${ }^{17}$ It should be noted that while it is possible for T to alternate as (second) OBJ and SUBJ in Balinese, native speakers of Balinese would often consider that $G$ alternates more easily than $T$.

${ }^{18}$ One could, perhaps, alternatively use the labels 'semi-oblique', 'prepositionally marked core', or 'oblique object': this is simply a matter of terminological preference.

${ }^{19} \mathrm{An}$ index interval of 0.20 is be used in the classification because five classes are established.

${ }^{20}$ Due to limitation of space, only one non-Indonesian language is discussed but this comparative study can be replicated with other (Austronesian) languages.

${ }^{21}$ Arguments against antipassive analysis for AV/AF structures in Austronesian languages of the Philippine type have been put forward in the literature (William A Foley, 2008, among others; Katagiri, 2005). Proponents for antipassive analysis include (Payne, 1982), (Cooreman, Fox, \& Givón, 1984), (Gerdts, 1988), (De Guzman, 1988), (Mithun, 1994), and (Aldridge, 2009). How to best analyse voice alternations in Austronesian languages is controversial, and the competing analyses will not be discussed further in this paper.

${ }^{22}$ The general property of thematic restrictedness is ignored in the comparison table because we are investigating a specific role of 'stimulus' in these three constructions.

${ }^{23}$ Musgrave (2001) classifies the stimulus of [SUKA NP] as an 'object-theta' in LFG, equivalent to the second object or $\mathrm{T}$ of the ditransitive verb. Note that the core index analysis in this paper supports Musgrave's analysis in that core indices of both Indonesian T/object-theta (0.57) and the stimulus NP of [SUKA NP] (0.50) are classifiable as Semi Core.

${ }^{24}$ It should also be noted that a verb such as 'eat' without an overt NP object is not necessarily intransitive, as it is treated as transitive in certain aspects, e.g., causativisation. Also, a verb that has both subject prefix and object suffix is not necessarily transitive, as with a restricted number of verbs the two affixes may co-refer and the verb is intransitive.

$$
\begin{array}{llll}
\text { no-wila-nono'o-ke } & \text { na } & \text { amai } & \\
\text { 3R-go-be.six-3OBJ } & \text { NOM } & \text { they } & \\
\text { 'All six of them went.' } & & & \text { (Donohue 1998: 96) }
\end{array}
$$

${ }^{25}$ Further investigation is needed on the exact structural position of the optional te-NP in (20). If it is in an object position rather than an oblique/adjunct position and if the structural object position is added to the list of core properties in Tukang Besi (which would then be five of them), then the stimulus argument can be classified as semi-core rather than oblique because it would satisfy two out of five core properties (with a core index of 0.40 ).

${ }^{26}$ The verb 'give' in Pendau always requires an applicative suffix (Quick 2007: 288-289).

${ }^{27}-a k$ (25) and -ik (26) are allomorphs of the same applicative suffix, -Vk; see Bowden (2001: 66-70) for the phonological conditions of the allomorphs.

${ }^{28}$ A detailed argument-structure analysis of the core/non-core alternation of this type in the Nusa Tenggara languages of Indonesia is discussed in Arka (2008).

${ }^{29} \mathrm{This}$ is not a problem for typologists and descriptivists, who generally recognise the fuzzy borderlines between cores and obliques, as evidenced from their terminology, such as 'oblique-core' and 'obliqueobject'. It is also certainly not a problem for theories that use the labels 'object' and 'oblique' informally, not as part of their basic theoretical construct, e.g., transformational grammar in its different versions (GB, PP, Minimalist) (Chomsky, 1981, 1995; Webelhuth, 1995), Construction Grammar as outlined in (Croft, 2001), and RRG (William A. Foley \& Van Valin, 1984; Van Valin Jr. \& LaPolla, 1999). However, there is a potential problem for a framework that does not have grammatical functions as discrete categories in that it may fall into the 'gradient-is-everywhere' trap: gradience is always posited when elements are difficult to categorise, giving rise to descriptions replete with unwarranted continuities 
(Aarts, 2007). Moreover, as Mary Dalrymple pointed out (p.c.), if we think of grammatical functions as prototypes that various properties tend to cluster around, we expect something more like Table 3, with languages differing in how they deploy the (primitive) prototypes. However, this is not what we find cross-linguistically.

${ }^{30}$ It should be noted that the term COMP (in capital letters) in LFG refers to a specific clausal grammatical function distinct from OBJ and OBL, e.g. the that-clause in English as in People believed that Obama was a Muslim. Clausal complements do not all behave the same (e.g., some are object-like and others are oblique-like) and their analysis as a distinct grammatical function is debatable (A Alsina et al., 2005; Dalrymple \& Lødrup, 2000).

${ }^{31}$ The question of whether an argument is or is not a core is of interest to syntacticians, rather than to the ordinary (native) speaker of a language. The speaker generally does not worry about whether something is really a core or not. Rather, s/he is generally concerned with the related 'meaning(s)' (implied) such as whether something is or is not affected. A similar point is made by Dowty (1991) in relation to the problem of determining the number, definition, and boundaries of thematic roles, e.g., whether an argument is a Theme, Source, etc.

${ }^{32}$ Purwo (1989) discusses the discourse factors underlying AV (meN-) verbs, UV ( $\varnothing$-) verbs, and diverbs, focusing on the different forms and positions of core arguments (A and $\mathrm{P}$ ). With respect to diverbs, he found that di- -nya signals that the verb is not emphasized (in contrast to dia $\varnothing$-verb), and that the referent of -nya is 'thematic' (i.e., described further in the succeeding clauses, i.e., -nya maintains topic continuity). He also notes that the NP agent of di- can be generic or non-generic but does not discuss it any further, nor does he investigate the discourse factors behind the PP agent of the di-verb.

${ }^{33}$ Pastika (1999) mainly discusses the pragmatics of the main core arguments in Balinese. 